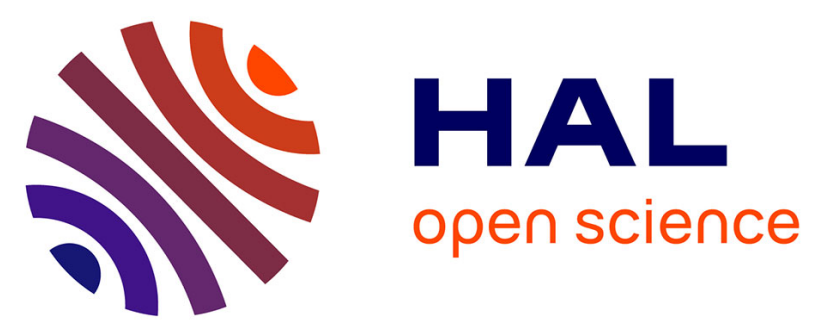

\title{
The sulfur cycle at high-southern latitudes in the LMD-ZT General Circulation Model
}

Emmanuel Cosme, Christophe Genthon, Patricia Martinerie, Olivier Boucher, Maï Pham

\section{To cite this version:}

Emmanuel Cosme, Christophe Genthon, Patricia Martinerie, Olivier Boucher, Maï Pham. The sulfur cycle at high-southern latitudes in the LMD-ZT General Circulation Model. Journal of Geophysical Research: Atmospheres, 2002, 107 (D23), pp.4690. 10.1029/2002JD002149 . hal-00203650

\section{HAL Id: hal-00203650 \\ https://hal.science/hal-00203650}

Submitted on 24 Jan 2016

HAL is a multi-disciplinary open access archive for the deposit and dissemination of scientific research documents, whether they are published or not. The documents may come from teaching and research institutions in France or abroad, or from public or private research centers.
L'archive ouverte pluridisciplinaire HAL, est destinée au dépôt et à la diffusion de documents scientifiques de niveau recherche, publiés ou non, émanant des établissements d'enseignement et de recherche français ou étrangers, des laboratoires publics ou privés. 


\title{
The sulfur cycle at high-southern latitudes in the LMD-ZT General Circulation Model
}

\author{
E. Cosme, C. Genthon, and P. Martinerie \\ Laboratoire de Glaciologie et Géophysique de l'Environnement, CNRS/OSUG, Saint-Martin-d'Hères, France \\ O. Boucher \\ Laboratoire d'Optique Atmosphérique, Université des Sciences et Technologies de Lille, CNRS, Villeneuve d'Ascq, France
}

M. Pham

Service d'Aronomie, Université Pierre et Marie Curie, Paris, France

Received 29 January 2002; revised 5 August 2002; accepted 6 August 2002; published 6 December 2002.

[1] This modeling study was motivated by the recent publication of year-round records of dimethylsulfide (DMS) and dimethylsulfoxide (DMSO) in Antarctica, completing the available series of sulfate and methanesulfonic acid (MSA). Sulfur chemistry has been incorporated in the Laboratoire de Météorologie Dynamique-Zoom Tracers (LMD-ZT) Atmospheric General Circulation Model (AGCM), with high-resolution and improved physics at high-southern latitudes. The model predicts the concentration of six major sulfur species through emissions, transport, wet and dry deposition, and chemistry in both gas and aqueous phases. Model results are broadly realistic when compared with measurements in air and snow or ice, as well as to results of other modeling studies, at high- and middlesouthern latitudes. Atmospheric MSA concentrations are underestimated and DMSO concentrations are overestimated in summer, reflecting the lack of a DMSO heterogeneous sink leading to MSA. Experiments with various recently published estimates of the rate of this sink are reported. Although not corrected in this work, other defects are identified and discussed: DMS concentrations are underestimated in winter, MSA and non-sea-salt (nss) sulfate concentrations may be underestimated at the South Pole, the deposition scheme used in the model may not be adapted to polar regions, and the model does not adequately reproduces interannual variability. Oceanic DMS sources have a major contribution to the variability of sulfur in these regions. The model results suggest that in a large part of central Antarctica ground-level atmospheric DMS concentrations are larger in winter than in summer. At high-southern latitudes, high loads of DMS and DMSO are found and the main chemical sink of sulfur dioxide $\left(\mathrm{SO}_{2}\right)$ is aqueous oxidation by ozone $\left(\mathrm{O}_{3}\right)$, whereas oxidation by hydrogen peroxide $\left(\mathrm{H}_{2} \mathrm{O}_{2}\right)$ dominates at the global scale. A comprehensive modeled sulfur budget of Antarctica is provided. INDEX TERMS: 0305 Atmospheric Composition and Structure: Aerosols and particles (0345, 4801); 0312 Atmospheric Composition and Structure: Air/sea constituent fluxes (3339, 4504); 0368 Atmospheric Composition and Structure: Troposphere - constituent transport and chemistry; 3319 Meteorology and Atmospheric Dynamics: General circulation; 9310 Information Related to Geographic Region: Antarctica; KEYWORDS: Antarctica, sulfur cycle, general circulation model, dimethylsulfide, ocean-atmosphere flux, tropospheric chemistry

Citation: Cosme, E., C. Genthon, P. Martinerie, O. Boucher, and M. Pham, The sulfur cycle at high-southern latitudes in the LMDZT General Circulation Model, J. Geophys. Res., 107(D23), 4690, doi:10.1029/2002JD002149, 2002.

\section{Introduction}

[2] Sulfur is considered as a key contributor to the climate forcing mechanisms [IPCC, 2001]. The submicronic sulfate and methanesulfonic acid (MSA) aerosols formed by gas-to-particle conversion interact with radiation both directly and indirectly through their action as Cloud

Copyright 2002 by the American Geophysical Union. 0148-0227/02/2002JD002149
Condensation Nuclei [Charlson et al., 1992]. This phenomenon leads primarily to a cooling effect of the Earth surface. Reciprocally, climatic conditions can affect biological activity and the production by the marine biota of dimethylsulfide (DMS), the main natural precursor of sulfur aerosols in the Southern Hemisphere. This feedback loop has already been suspected to act as a self-regulating process of the climate system [Shaw, 1983; Charlson et al., 1987]. But since the 18th century and the industrial development, anthropogenic sulfur dioxide $\left(\mathrm{SO}_{2}\right)$ emissions dominate 
the natural emissions, and this self-regulation, if it exists, is not operative anymore in the Northern Hemisphere [Charlson, 1993]. To study the natural sulfur cycle is a necessary step toward a better understanding of human influence on the interaction between climate and the sulfur cycle.

[3] Sulfate measurements in recent Antarctic snow layers revealed that man-made activity does not have a significant impact on the sulfur cycle at high-southern latitudes [see Legrand, 1997 for a review]. These regions thus represent an ideal observation point for elucidating the interactions between climate and natural sulfur cycle. Moreover, the interpretation of Antarctic ice core records, in terms of climate forcing or response, requires a good understanding of the processes that drive the MSA/non-sea-salt (nss) sulfate ratio at middle- and high-southern latitudes. Bates et al. [1992a] found a temperature dependence of the MSA/nss sulfate ratio in the marine environment, interpreted as a more efficient $\mathrm{OH}$-addition channel of DMS oxidation at lower temperatures [Hynes et al., 1986; Ravishankara et al., 1997]. Assuming a latitude dependence of temperature, this ratio can then be used, at a given site, to determine the latitude region where MSA and nss sulfate were formed [Legrand et al., 1992]. However, because other parameters such as oxidant concentrations can also influence the ratio [Hynes et al., 1986; Toumi, 1994; Patroescu et al., 1996], a clear and comprehensive picture of the sulfur cycle and its influencing environment is needed to use this method. To study the climate-sulfur cycle interactions on the one hand, and to access a 3D picture of the sulfur cycle and its atmospheric environment on the other hand, an Atmospheric General Circulation Model (AGCM) seems particularly appropriate.

[4] The sulfur aerosol concentrations (MSA, sulfate) in south polar regions are now documented with multiple yearround measurements at several Antarctic coastal stations like those of CAASC project [Wolff et al., 1998b; Minikin et al., 1998] and Savoie et al. [1993], as well as shorter summer campaigns such as SCATE [Berresheim and Eisele, 1998; Berresheim et al., 1998; Jefferson et al., 1998a, 1998b], ISCAT [Mauldin et al., 2001; Arimoto et al., 2001], and, for the Southern Ocean regions, ACE 1 [Bates et al., 1998; De Bruyn et al., 1998; Blake et al., 1999]. Moreover, for the first time, the major gaseous sulfur species DMS and dimethylsulfoxide (DMSO) have been measured continuously over several years (including winter months), at the Antarctic coastal station Dumont d'Urville (Figure 1) [Jourdain and Legrand, 2001; Jourdain, 2001]. Therefore, measurements of sulfur compounds in the Antarctic region now constitute a significantly detailed data set for a 3D model evaluation.

[5] This paper presents a study of the sulfur cycle at highsouthern latitudes with an AGCM. We use a modified version, optimized for south polar regions, of the Laboratoire de Météorologie Dynamique-Zoom Tracers (LMD-ZT) sulfur model. The main characteristics of the model are presented in section 2 . In section 3, the simulated seasonal cycle of atmospheric concentrations is compared to yearround observations. In section 4 , simulated snow concentrations and deposition fluxes of nss sulfate and MSA are compared to measurements in firn and ice cores. In section 5 , LMD-ZT results are compared to results of other $3 \mathrm{D}$ models. In section 6 , the model ability to represent temporal variability of the sulfur cycle is evaluated. In section 7, a

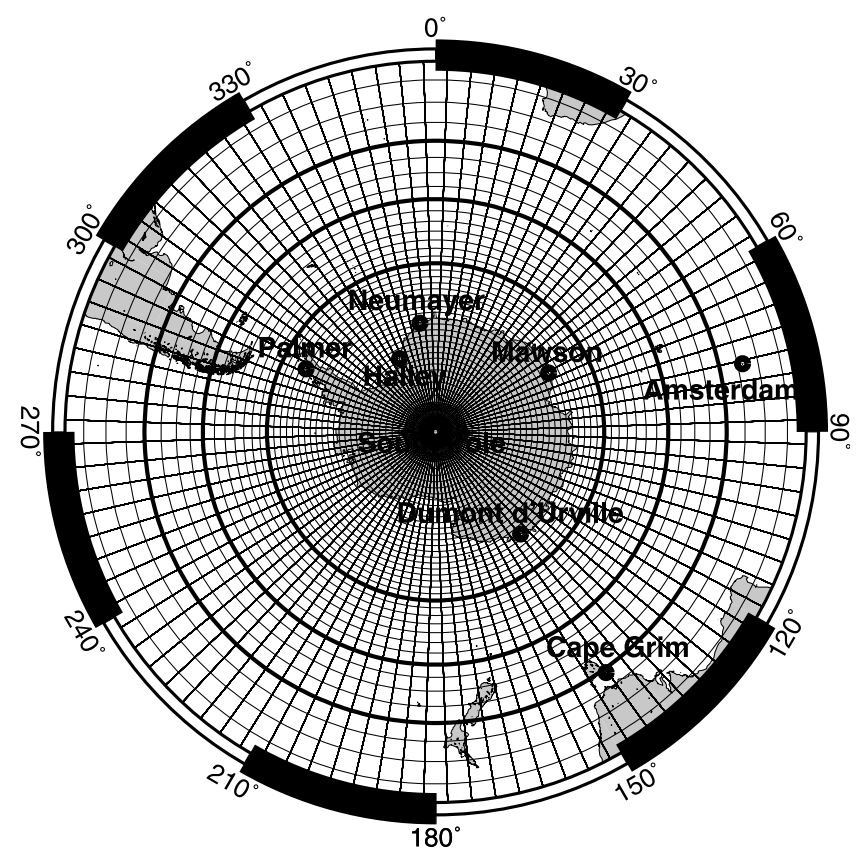

Figure 1. Antarctic and subantarctic monitoring stations for which published time series of sulfur species concentrations, mostly MSA and nss sulfate in aerosols, enable the study of a consistent seasonal cycle. The thin solid lines represent the zoomed grid, and the three bold lines represent the latitudes forced with ECMWF data.

sensitivity test on oceanic DMS sources, motivated by the results of the previous sections, is presented. In section 8 , we finally present some global characteristics of the atmospheric sulfur cycle and budget over Antarctica, as simulated by the model.

\section{Model Description}

[6] We use the LMD-ZT AGCM. Specific physical parameterizations developed by Krinner et al. [1997] have been implemented to improve the polar atmospheric physics. The grid has 96 (longitude) $\times 72$ (latitude) points. It is regular in longitude with a resolution of $3.75^{\circ}$, but stretched in latitude to reach a resolution of $1^{\circ}$ between $66^{\circ} \mathrm{S}$ and $76^{\circ} \mathrm{S}$. This leads to a resolution of $\sim 100 \mathrm{~km}$ in both latitude and longitude in this region (Figure 1).

[7] There are 19 vertical levels described with a hybrid $\sigma$ pressure coordinate, with the first level centered at around $12 \mathrm{~m}$ above the ground. The primitive equations are solved with a time step of $1.5 \mathrm{~min}$, large-scale advection every 7.5 min, and the physical and chemical parameterizations every $30 \mathrm{~min}$. Atmospheric transport is computed with a finite volume transport scheme for large-scale advection [Van Leer, 1977; Hourdin and Armengaud, 1999], a scheme for turbulent mixing in the boundary layer, and a mass flux scheme for convection [Tiedtke, 1989].

[8] The original sulfur treatment, including emissions, chemistry, and deposition, is described in details by Boucher et al. [2002]. Six sulfur species are computed: DMS, $\mathrm{SO}_{2}$, nss sulfate $\left(\mathrm{SO}_{4}{ }^{2-}\right)$, hydrogen sulfide $\left(\mathrm{H}_{2} \mathrm{~S}\right)$, DMSO, and MSA. For sulfate and MSA, only the particulate phase is considered. Surface emissions of DMS, $\mathrm{SO}_{2}$, 
Table 1. Reaction Rates Used in the Present Study

\begin{tabular}{|c|c|c|}
\hline Reaction & Rate & Reference \\
\hline $\mathrm{DMS}+\mathrm{OH} \rightarrow \mathrm{SO}_{2}+\ldots$ & $\begin{array}{l}\text { Gaseous-phase chemistry } \\
K_{1}=9.6 \times 10^{-12} e^{-234 / \mathrm{T}}\end{array}$ & $\begin{array}{l}\mathrm{a} \\
\mathrm{b}\end{array}$ \\
\hline $\mathrm{DMS}+\mathrm{OH} \rightarrow x \mathrm{SO}_{2}+(1-x) \mathrm{DMSO}+\ldots$ & $\left\{\begin{array}{c}K_{2}=3.0410^{-12} e^{350 / T} \alpha /(1+\alpha) \\
\alpha=1.1510^{-31} e^{7460 / T}[M] x=0.6\end{array}\right.$ & $\mathrm{c}$ \\
\hline $\begin{array}{l}\mathrm{DMS}+\mathrm{NO}_{3} \rightarrow \mathrm{SO}_{2}+\ldots \\
\mathrm{SO}_{2}+\mathrm{OH} \rightarrow \text { sulfate }+\ldots\end{array}$ & $\begin{array}{l}K_{3}=1.9 \times 10^{-13} e^{500 / T} \\
\left\{\begin{array}{c}K_{4}=\alpha[M] /(1+\alpha[M]) / 1.510^{-12} .0 .6^{\beta} \\
\alpha=3.010^{-31}(300 / T)^{3.3}\end{array}\right.\end{array}$ & c \\
\hline & $\left(\beta=1 /\left(1+\log _{10}\left(\alpha[M] / 1.510^{-12}\right)\right)^{2}\right.$ & b \\
\hline $\mathrm{DMSO}+\mathrm{OH} \rightarrow x \mathrm{SO}_{2}+(1-x) \mathrm{MSA}+\ldots$ & $K_{5}=5.8 \times 10^{-11} x=0.6$ & $\mathrm{c}$ \\
\hline $\mathrm{H}_{2} \mathrm{~S}+\mathrm{OH} \rightarrow \mathrm{SO}_{2}+\ldots$ & $K_{6}=6.0 \times 10^{-12} e^{-75 / T}$ & $c$ \\
\hline $\mathrm{HO}_{2}+\mathrm{HO}_{2} \rightarrow \mathrm{H}_{2} \mathrm{O}_{2}+\ldots$ & $\left\{\begin{array}{c}K_{7}=2.310^{-13} e^{600 / T}+1.710^{-33}[M] e^{1000 / T} \\
\text { corrected for the effect of water vapor }\end{array}\right.$ & $\mathrm{c}$ \\
\hline $\begin{array}{l}\mathrm{H}_{2} \mathrm{O}_{2}+\mathrm{OH} \rightarrow \mathrm{HO}_{2}+\mathrm{H}_{2} \mathrm{O} \\
\mathrm{H}_{2} \mathrm{O}_{2}+\mathrm{h} \nu \rightarrow 2 \mathrm{OH}\end{array}$ & $\begin{array}{l}K_{8}=2.9 \times 10^{-12} e^{-160 / T} \\
\text { Prescribed from IMAGES }\end{array}$ & $\mathrm{c}$ \\
\hline $\mathrm{S}(\mathrm{IV})+\mathrm{H}_{2} \mathrm{O}_{2} \rightarrow$ sulfate & $\begin{array}{c}\text { Aqueous-phase chemistry } \\
K_{11}^{\mathrm{aq}}=7.5 \times 10^{7} e^{-4430(1 / T-1 / 298 .)}\left[\mathrm{H}^{+}\right]_{\mathrm{aq}} /\left(1+13\left[\mathrm{H}^{+}\right]_{\mathrm{aq}}\right)\end{array}$ & $\begin{array}{l}\mathrm{d} \\
\mathrm{d}\end{array}$ \\
\hline $\mathrm{S}(\mathrm{IV})+\mathrm{O}_{3} \rightarrow$ sulfate & $\left\{\begin{array}{c}K_{21}^{\mathrm{aq}}=2.410^{4} \\
K_{22}^{\mathrm{aq}}=3.710^{5} e^{-5530(1 / T-1 / 298 .)} \\
K_{23}^{\mathrm{aq}}=1.510^{9} e^{-5280(1 / T-1 / 298 .)}\end{array}\right.$ & \\
\hline DMSO & $5 \times 10^{4} \quad$ Solubility constants & e \\
\hline $\mathrm{SO}_{2}$ & $1.4 e^{2900(1 / T-1 / 298}$ & f \\
\hline $\mathrm{H}_{2} \mathrm{O}_{2}$ & $8.3 \times 10^{4} e^{7400(1 / T-1 / 298)}$ & $\mathrm{g}$ \\
\hline $\mathrm{O}_{3}$ & $1.15 \times 10^{-2} e^{2560(1 / T-1 / 298 .)}$ & $\mathrm{h}$ \\
\hline $\begin{array}{l}\mathrm{SO}_{2} / \mathrm{SO}_{3}^{-} \\
\mathrm{SO}_{3}^{-} / \mathrm{SO}_{3}^{2-}\end{array}$ & $\begin{aligned} & \text { Dissociation constants } \\
& 1.3 \times 10^{-2} e^{1960(1 / T-1 / 298 .)} \\
& 6.6 \times 10^{-8} e^{1500(1 / T-1 / 298)}\end{aligned}$ & $\begin{array}{l}\mathrm{d} \\
\mathrm{d}\end{array}$ \\
\hline $\mathrm{DMSO} \rightarrow \mathrm{MSA}$ & $\begin{array}{l}\text { eous-phase chemistry (only for a sensitivity experiment) } \\
1:\left(0.5 \times 10^{-10}[\mathrm{OH}]+5.5 \times 10^{-5}\right) \mathrm{S} / 3.3 \\
2: 2 \times 10^{-4} \mathrm{~S} / 10.5 \\
3: 2.4 \times 10^{-10}[\mathrm{OH}](\text { and DMSO yield for DMS }+\mathrm{OH} \text { divided by } 2) \\
\text { 4: }\left(0.5 \times 10^{-10}[\mathrm{OH}]+5.5 \times 10^{-5}\right) \mathrm{S} / 60\end{array}$ & $\begin{array}{c}\mathrm{i} \\
\mathrm{j} \\
\mathrm{k} \\
\text { (derived from) }^{\mathrm{i}}\end{array}$ \\
\hline
\end{tabular}

Units are $\mathrm{cm}^{3} \mathrm{~mol}^{-1} \mathrm{~s}^{-1}$ for the gas-phase reaction rates $\left(K_{i}\right), 1 \mathrm{~mol}^{-1} \mathrm{~s}^{-1}$ for aqueous-phase reaction rates $\left(K_{i j}^{\mathrm{aq}}\right)$, mol $\mathrm{l}^{-1}$ atm ${ }^{-1}$ for solubility constants, and $\mathrm{mol} 1^{-1}$ for dissociation constants. $S$ is the dry aerosol surface in $\mu \mathrm{m}^{2} \mathrm{~cm}^{-3} \cdot \frac{\partial\left[\mathrm{S}_{\mathrm{i}}\right] \mathrm{aq}}{\partial t}=-K_{11}^{\mathrm{aq}}\left[\mathrm{H}_{2} \mathrm{O}_{2}\right]_{\mathrm{aq}}\left[\mathrm{HSO}_{3}^{-}\right]_{\mathrm{aq}} \frac{\partial\left[\mathrm{S}_{\mathrm{i}}\right] \mathrm{aq}}{\partial t}=-\left(K_{21}^{\mathrm{aq}}\left[\mathrm{SO}_{2} \cdot \mathrm{H}_{2} \mathrm{O}\right]_{\mathrm{aq}}\right.$ $\left.+K_{22}^{\mathrm{aq}}\left[\mathrm{HSO}_{3}^{-}\right]_{\mathrm{aq}}+K_{23}^{\mathrm{aq}}\left[\mathrm{SO}_{3}^{2-}\right]_{\mathrm{aq}}\right)\left[\mathrm{O}_{3}\right]_{\mathrm{aq}}$.

a Atkinson et al. [1989].

${ }^{\mathrm{b}}$ Chatfield and Crutzen [1990].

${ }^{\mathrm{c}}$ DeMore et al. [1997].

${ }^{\mathrm{d}}$ Seinfeld and Pandis [1998].

${ }^{\mathrm{e}}$ Sander [1999].

${ }^{\mathrm{f}}$ Lide and Frederikse [1995].

${ }^{g}$ O'Sullivan et al. [1996].

${ }^{\mathrm{h}}$ National Bureau of Standards [1965].

${ }^{\mathrm{i}}$ Legrand et al. [2001].

${ }^{\mathrm{j}}$ Davis et al. [1998].

${ }^{\mathrm{k}}$ Sciare et al. [2000a].

and $\mathrm{H}_{2} \mathrm{~S}$ are considered. The DMS fluxes are derived from the sea surface DMS concentrations maps of Kettle et al. [1999] using the sea-to-air parameterization of Liss and Merlivat [1986]. Emission fluxes are precomputed using climatological wind and temperature fields. Because they constitute a climatology, these oceanic DMS fluxes do not feature any interannual variability. All species are transported and undergo dry and wet deposition. Prescribed fields from a 3D atmospheric chemistry model (IMAGES) [Müller and Brasseur, 1995] are used for photodissociation rates of hydrogen peroxide $\left(\mathrm{H}_{2} \mathrm{O}_{2}\right)$ and oxidant concentrations (namely hydroxyl $\mathrm{OH}$, hydroperoxyl $\mathrm{HO}_{2}$, nitrate $\mathrm{NO}_{3}$ radicals, and ozone $\left(\mathrm{O}_{3}\right)$ ). $\mathrm{H}_{2} \mathrm{O}_{2}$, because its concentration can be affected by the sulfur cycle upon aqueous oxidation of $\mathrm{SO}_{2}$, is also a prognostic variable. Its chemical production and destruction by nonsulfur compounds result from 3 reactions (see Table 1). The gas-phase chemical scheme for sulfur species is a simplified version of the one by Pham et al. [1995] (Table 1). It features DMS $+\mathrm{NO}_{3}$ reaction leading to $\mathrm{SO}_{2}$, DMS $+\mathrm{OH}$ addition and abstraction channels leading to DMSO and $\mathrm{SO}_{2}, \mathrm{DMSO}+\mathrm{OH}$ reaction leading to MSA and $\mathrm{SO}_{2}, \mathrm{SO}_{2}+\mathrm{OH}$ leading to sulfate, and $\mathrm{H}_{2} \mathrm{~S}+\mathrm{OH}$ leading to $\mathrm{SO}_{2}$. The aqueous-phase scheme involves the oxidation of $\mathrm{SO}_{2}$ by $\mathrm{O}_{3}$ and $\mathrm{H}_{2} \mathrm{O}_{2}$.

[9] In order to improve the model climatology and introduce a realistic meteorological variability, the model 


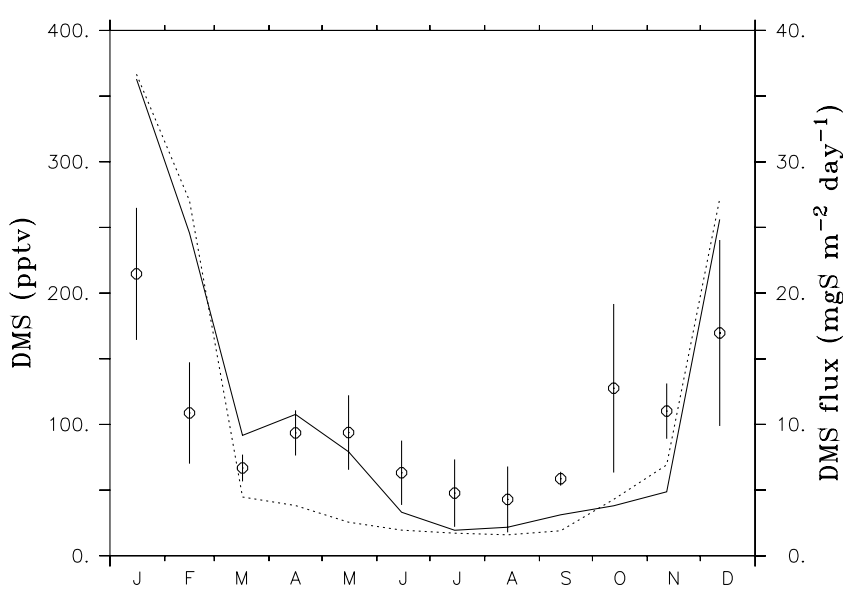

Figure 2. Seasonal variations of DMS (pptv, left-hand axis) at Dumont d'Urville $\left(140^{\circ} 1^{\prime} \mathrm{E}, 66^{\circ} 40^{\prime} \mathrm{S}\right)$. Open circles represent observations [Jourdain, 2001]. Vertical lines are standard deviations of monthly values (representing year-toyear variability). Simulation results are symbolized by the solid line. The dotted line represents the local oceanic DMS fluxes ( $\mathrm{mg} \mathrm{m}^{-2} \mathrm{~d}^{-1}$, right-hand axis) in the model.

is run with a "lateral nudging" of Antarctic atmospheric circulation, as described by Genthon et al. [2002]. To take the best advantage of the good behavior of the model in polar regions [Krinner et al., 1997], nudging is not performed at every grid point but only at the periphery of the Antarctic region. A total nudging is applied near $60^{\circ} \mathrm{S}$, $50^{\circ} \mathrm{S}$, and $40^{\circ} \mathrm{S}$ (see Figure 1) for surface pressure, zonal and meridional wind from ECMWF analyses. Genthon et al. [2002] stress the potential of lateral nudging for constraining the transport of tracers from middle to high latitudes.

[10] The model is run over the 1993-1999 period (7 years), with the corresponding surface boundary conditions (including sea ice fraction) and nudging. The first 2 years are used to spin up tracer concentrations in the modeled atmosphere. Only the last 5 years are considered in the following discussion.

\section{Seasonal Cycle of Atmospheric Concentrations 3.1. DMS}

[11] Since December 1998, atmospheric DMS has been measured continuously at Dumont d'Urville. It is the first year-round monitoring of DMS in Antarctica and the record is now covering 3 years [Joudain, 2001]. Measurements are made a few meters above the ground, and can thus be compared to simulated concentrations at the first level of the model $(\sim 12 \mathrm{~m})$.

[12] A comparison of observed and modeled mixing ratios is presented on Figure 2. The strong seasonal cycle of DMS is well reproduced by the model, and mixing ratios are correctly simulated, within a factor of 2 . They are overestimated in summer and underestimated in winter. The plot shows that simulated DMS concentrations are closely linked to the oceanic fluxes in the model grid box corresponding to the station, suggesting that these discrepancies are related to the prescribed DMS emissions. Kettle et al. [1999] stress the rather small number of DMS measurements available in Southern Ocean waters. Consequently, large uncertainties still linger in the DMS fluxes imposed to the model in the Antarctic region. At lower latitudes, where oceanic DMS concentrations have been measured more frequently, the model reproduces well the observed DMS seasonal cycle. This is shown on Figure 3, that depicts observed and simulated DMS mixing ratios at Amsterdam Island [Nguyen et al., 1990; Sciare et al., 2000a], and Cape Grim [Ayers et al., 1995] (Figure 1). Moreover, DMS measurements at Dumont d'Urville present a perceptible year-to-year variability [Jourdain, 2001]: modeled values fit better the observations of winter 2001 (primarily, the bottom of error bars, Figure 2) than those of winter 1999 (top of the error bars). The high DMS load during winter 1999 could be linked to relatively exceptional sea ice conditions offshore Dumont d'Urville in this period, as mentioned by Jourdain and Legrand [2001]. Indeed,
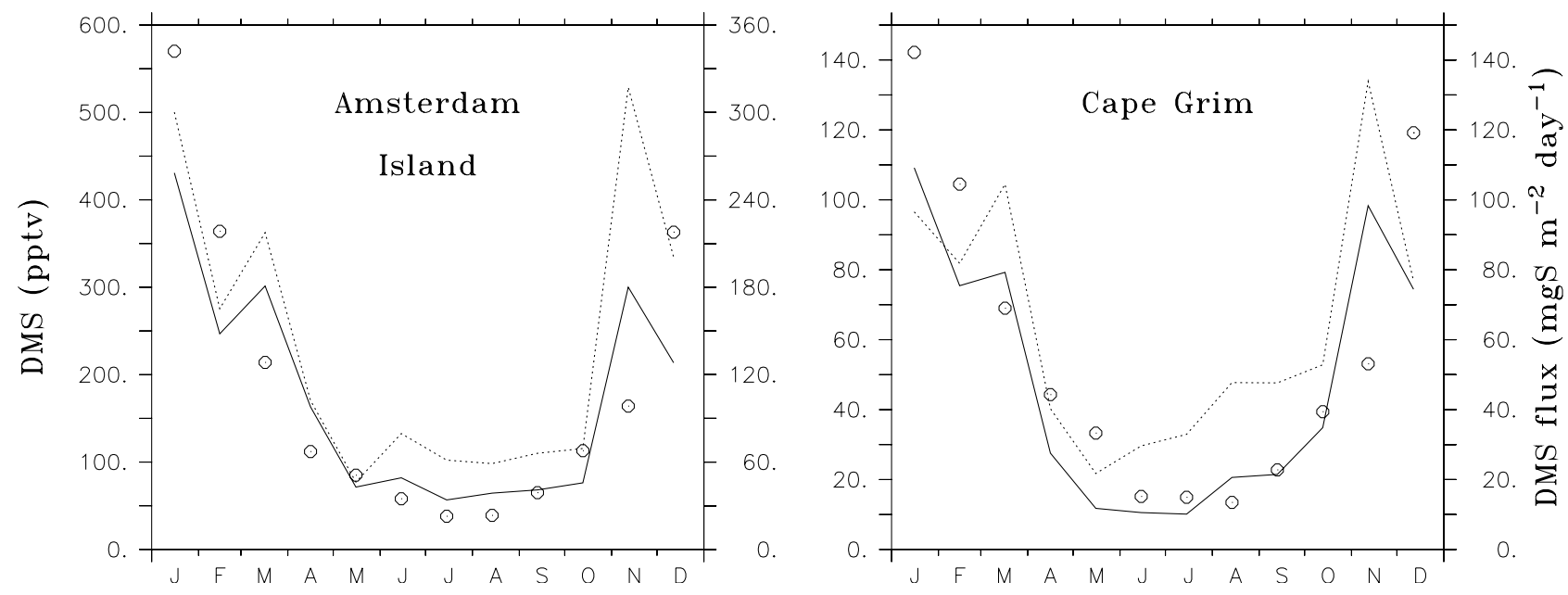

Figure 3. Same as Figure 2 for Amsterdam Island $\left(77^{\circ} 30^{\prime} \mathrm{E}, 37^{\circ} 50^{\prime} \mathrm{S}\right.$ ) (observations by Ngyuyen et al. [1990] and Sciare et al. [2000a]) and Cape Grim $\left(144^{\circ} 41^{\prime} \mathrm{E}, 40^{\circ} 41^{\prime} \mathrm{S}\right)$ [Ayers et al., 1995]. 


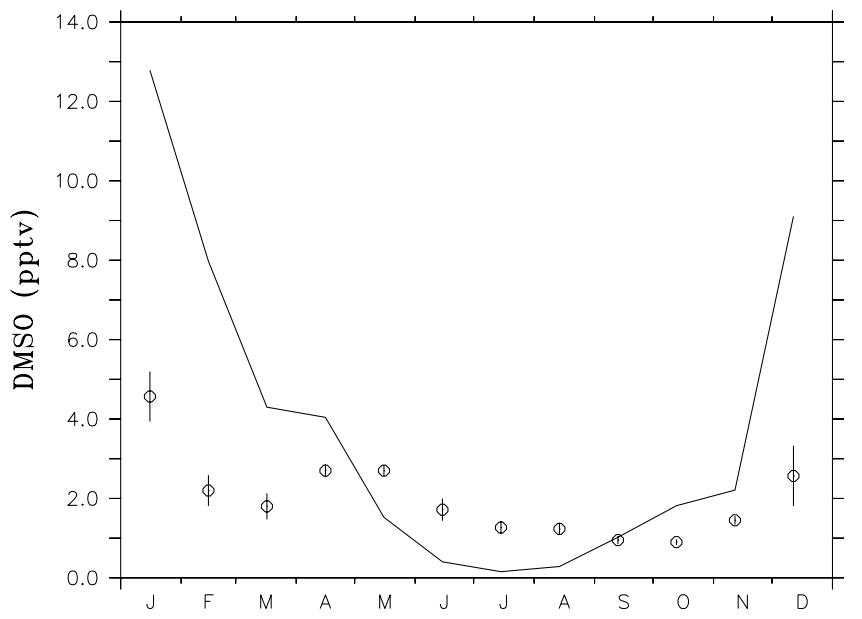

Figure 4. Seasonal variations of DMSO (pptv) at Dumont d'Urville. Open circles represent observations [Jourdain, 2001]. Simulation results are represented by the solid line.

intense DMS releases have already been observed in the presence of sea ice [e.g., Kleefeld, 1998; Curran et al., 1998; Inomata et al., 1997]. A sensitivity experiment, reported in section 7, shows that atmospheric DMS near the Antarctic coastal regions is highly sensitive to sea ice conditions.

\subsection{DMSO}

\subsubsection{Dumont d'Urville}

[13] As for DMS, the only year-round monitoring of gasphase DMSO in Antarctica was performed at Dumont d'Urville, for 3 years [Jourdain, 2001]. Comparison with model results is presented in Figure 4. The model underestimates winter values, and this is consistent with similar results for DMS. This error is thus likely primarily linked to DMS emissions. However, it seems that the model underestimates DMSO concentrations more drastically than DMS, suggesting that DMS emissions are not the only reason of the discrepancy. A plausible explanation is the missing reaction of DMS with bromine oxide (BrO) [Toumi, 1994] in the model. The role of this reaction is still not well quantified, because the abundance of $\mathrm{BrO}$ in the atmosphere remains uncertain. However, a recent $1 \mathrm{D}$ study by von Glasow et al. [2002] suggests that consideration of $\mathrm{BrO}$ would increase the DMS oxidation rate by more than $50 \%$ in remote marine boundary layer conditions.

[14] The model overestimates summer DMSO by a factor of 3, whereas concentrations of the precursor, DMS, are better simulated. We know according to Davis et al. [1998] and Sciare et al. [2000a] that DMSO gas is efficiently scavenged by particles, and that this is a significant sink of DMSO. DMSO is then partly oxidized into MSA [Legrand et al., 2001]. Sciare et al. [2000a] find this process to be of similar efficiency as the DMSO oxidation by $\mathrm{OH}$ in the gas phase. If correct, simulated DMSO concentrations would approximately be divided by 2 , which would bring them in much better agreement with observations. To explore the possible impact of this process on DMSO (and MSA, see section 3.3), four sensitivity experiments have been devised using tentative formulations for the heterogeneous loss of
DMSO. Three different parameterizations, suggested by (1) Legrand et al. [2001], (2) Davis et al. [1998], and (3) Sciare et al. [2000a], respectively, are first tested. They represent in situ estimations from case studies performed in summer at Dumont d'Urville, Palmer and Amsterdam Island (Figure 1) respectively, and are formulated explicitly in Table 1 . The dry (sea-salt) aerosol surface, needed for parameterizations (1) and (2), is prescribed from the TM3 global atmospheric tracer transport model results [Guelle et al., 2001]. Because all parameterizations are based on summer observations only, the sensitivity tests were performed for January 1995. The results for DMSO and MSA at Dumont d'Urville are presented in Table 2.

[15] The parameterizations of Legrand et al. [2001] and Davis et al. [1998] leads to excessive DMSO oxidation and MSA production. The parameterization of Sciare et al. [2000a] leads to a better agreement with measurements for DMSO and MSA concentrations, but both are somewhat underestimated. However, the prescribed sea-salt aerosol surface, as simulated by TM3 at Dumont d'Urville in January, reaches $60 \mu \mathrm{m}^{2} \mathrm{~cm}^{-3}$ whereas the experimental estimation reported by Legrand et al. [2001] is of $3.3 \mu \mathrm{m}^{2}$ $\mathrm{cm}^{-3}$ only. An ad hoc corrective factor $(3.3 / 60)$ to the parameterization of Legrand et al. [2001] (experiment 4, Tables 1 and 2), brings DMSO and MSA mixing ratios in good agreement with observations.

[16] This short study highlights the uncertainties that presently prevent from routinely accounting for the heterogeneous oxidation of DMSO in global models:

1. Global evaluations of aerosols are available from models only, and they are not validated in the polar regions;

2 . The kinetics of the reaction has only been characterized locally, from in situ summer observations only. In addition, results obtained from the various proposed parameterizations are not in mutual agreement.

\subsubsection{Amsterdam Island}

[17] Although not located at high-southern latitudes but in the Southern Ocean, Amsterdam Island is one of the very few places, besides Dumont d'Urville, where a year-round series of DMSO measurements is available [Sciare et al., 2000a]. The comparison of model results with observations is shown on Figure 5. It turns out that the observed DMSO mixing ratio is well reproduced by the model all over the year. This is surprising, since the model potentially lacks a reaction of DMSO production (DMS $+\mathrm{BrO})$, and probably an heterogeneous sink of DMSO. Several reasons might explain this unexpected result:

1. The missing DMSO production and sink processes mentioned above cancel each other at Amsterdam Island;

Table 2. DMSO and MSA Mixing Ratios (pptv) and Ratio at Dumont d'Urville in January 1995, as Observed (Column Obs.), in our Reference Simulation (Ref.), With an Additional Reaction (See Text) Parameterized Following the Works of Legrand et al. [2001] (1), Davis et al. [1998] (2), Sciare et al. [2000a] (3), and Legrand et al. [2001] Modified (4)

\begin{tabular}{lcccccc}
\hline & Obs. & Ref. & $(1)$ & $(2)$ & $(3)$ & $(4)$ \\
\hline DMSO & 3.5 & 10.4 & 0.2 & 0.2 & 1.0 & 2.8 \\
MSA & 13.4 & 10.3 & 22.0 & 20.4 & 11.3 & 14.8 \\
DMSO/MSA & 0.25 & 1.0 & 0.05 & 0.06 & 0.17 & 0.19 \\
\hline
\end{tabular}




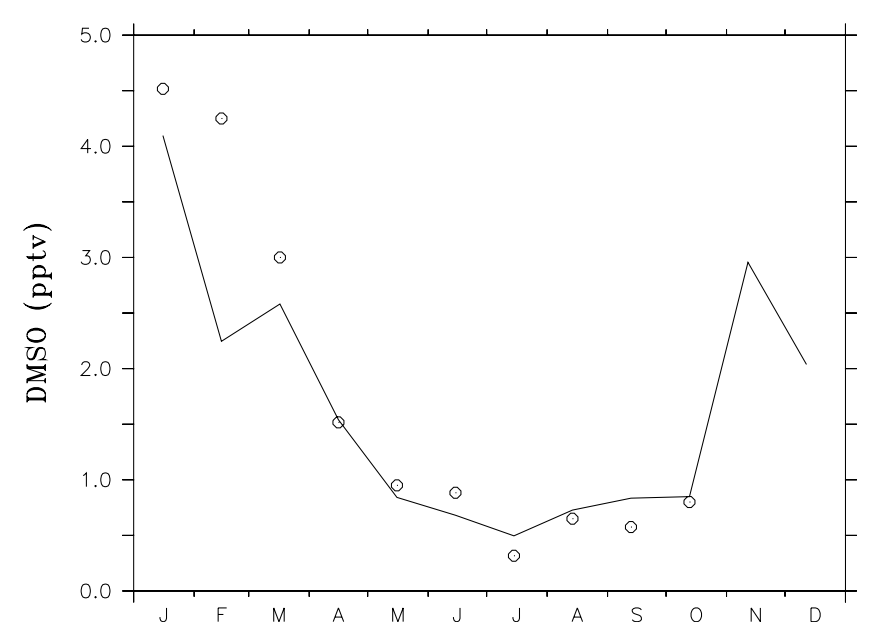

Figure 5. Same as Figure 4 for Amsterdam Island. Observations of DMSO are by Sciare et al. [2000a].

2. Both are weak at Amsterdam Island, compared with Dumont d'Urville. This implies that Sciare et al. [2000a] overestimate the rate of the heterogeneous DMSO sink. In fact, they assume that DMS is homogeneously distributed in $\mathrm{a} \sim 1150 \mathrm{~m}$ boundary layer. The model suggests that it is not the case, and that surface concentrations are about 8 times larger than concentrations at $1200 \mathrm{~m}$ elevation;

3. Sciare et al. [2000a] are correct to assume a well mixed boundary layer, and the model underestimates a possibly strong mixing associated with the relief of the island, which the model ignores due to resolution limitations.

Since a more intense boundary layer mixing of DMS would lead to lower DMS surface mixing ratios, case 3 would mean that oceanic DMS fluxes in the model are too low in the region of Amsterdam Island. Indeed, DMS mixing ratios are presently well simulated by the model (Figure 3). However, larger DMS fluxes would lead to larger DMSO mixing ratios, that would be consistent with the lack of the heterogeneous DMSO sink. Of course, the inverse argument is legitimate for case 2. Observation of the vertical DMS distribution at Amsterdam Island would obviously help solving this question. The sensitivity experiments (1-4) performed in section 3.2.1 respectively lead to DMSO mixing ratios, in January 1995, of $0.4,0.5,0.45$, and 1.9 pptv, which are consistently lower than the baseline simulation (4.1 pptv) and the observation (4.5 pptv), as expected.

[18] Conflicting results at Dumont d'Urville and Amsterdam Island thus confirm that currently available informations are insufficient to routinely account for and validate the missing oxidation reactions in global 3D models.

\subsection{NSS Sulfate and MSA Aerosols}

[19] Until recently, only nss sulfate and MSA, mainly present in the aerosol phase, were monitored on a yearround basis. Multiannual series are currently available for these species at several Antarctic coastal stations: Dumontd'Urville, Halley, Neumayer [Minikin et al., 1998], Palmer, and Mawson [Savoie et al., 1993] (see Figure 1).

[20] Figures 6 and 7show the mixing ratios of nss sulfate and MSA aerosols at these five stations for an average year.
For both compounds and at all stations the strong seasonal cycle, characterized by summer maxima, is reproduced by the model. Nss sulfate concentrations can be underestimated (Neumayer) or overestimated (Palmer in summer) but remain globally consistent (within a factor of 2) with observations. At all sites, MSA concentrations are systematically underestimated. This could be due to an incorrect prescription of the DMS sources, in terms of intensity and/ or location, or to an insufficient chemical production of MSA. Two evidences come in support of the second assumption. First, nss sulfate is better simulated at all stations, and sometimes overestimated (at Palmer). Second, DMSO is overestimated at Dumont d'Urville in summer (Figure 4), and the missing sink of DMSO (section 3.2) essentially leads to MSA formation. As at Dumont d'Urville (Table 2), the disagreement between simulated and observed MSA can be reduced when an ad hoc heterogeneous reaction is implemented in the model.

[21] MSA and sulfate aerosols have never been monitored on a year-round basis at any inland Antarctic site. However, at the South Pole, a few measurements of atmospheric concentrations of these compounds have been carried out in summer and, for sulfate, in winter [Tuncel et al., 1989; Cunningham and Waddington, 1993; Harder et al., 2000; Arimoto et al., 2001]. The observed and modeled atmospheric concentrations are presented in Table 3. The table also presents data that are discussed in section 4. Nss sulfate and MSA are underestimated by the model near the surface. A possible explanation for such a discrepancy has been suggested recently by Mauldin et al. [2001] who measured, during the ISCAT (Investigation of Sulfur Chemistry in the Antarctic Troposphere) project, unexpectedly high concentrations of $\mathrm{OH}$ radicals at the South Pole in summer. These high concentrations are due to high levels of NO, themselves due to a release of $\mathrm{NO}_{x}$ by the snow [Davis et al., 2001]. $\mathrm{NO}_{x}$ are formed through the photolysis of $\mathrm{NO}_{3}{ }^{-}$in the snowpack [Honrath et al., 1999]. The IMAGES model does not include any impact of in-snow chemistry on the atmospheric $\mathrm{OH}$ concentrations. Thus, in spite of a correct representation of $\mathrm{OH}$ near the coast (the prescribed $\mathrm{OH}$ concentration at Palmer in February, $\sim 1.6 \times 10^{5} \mathrm{~mol} \mathrm{~cm}^{-3}$, is rather consistent with SCATE results of $1.1 \times 10^{5} \mathrm{~mol}$ $\mathrm{cm}^{-3}$ [Jefferson et al., 1998b]), the prescribed OH concentration at the South Pole is 10 times lower than that found during ISCAT in summer. Obviously, this leads to an underestimation of concentrations of nss sulfate and MSA, but also to a likely overestimation of the concentration of their primary precursor: DMS. However, when cumulated, DMS, $\mathrm{SO}_{2}$, DMSO and nss sulfate sum up to only $22 \mathrm{ng}$ $\mathrm{m}^{-3}$ of sulfur, which if all converted into sulfate cannot account for more than $66 \mathrm{ng} \mathrm{m}^{-3}$ near the ground. Thus, it seems that $\mathrm{OH}$ underestimation is not the only reason for the low simulated aerosol concentrations. As a sensitivity experiment, the model has been run over January 1995 with $\mathrm{OH}$ concentrations multiplied by 10 at the first level of the model, in the presence of continental ice. No significant change has been observed in the nss sulfate and MSA concentrations, partly because the gaseous precursor concentrations are very low. Because MSA and nss sulfate concentrations display strong vertical gradients in the first levels of the model (concentrations are about 5-8 times larger at higher levels in the boundary layer), we believe 

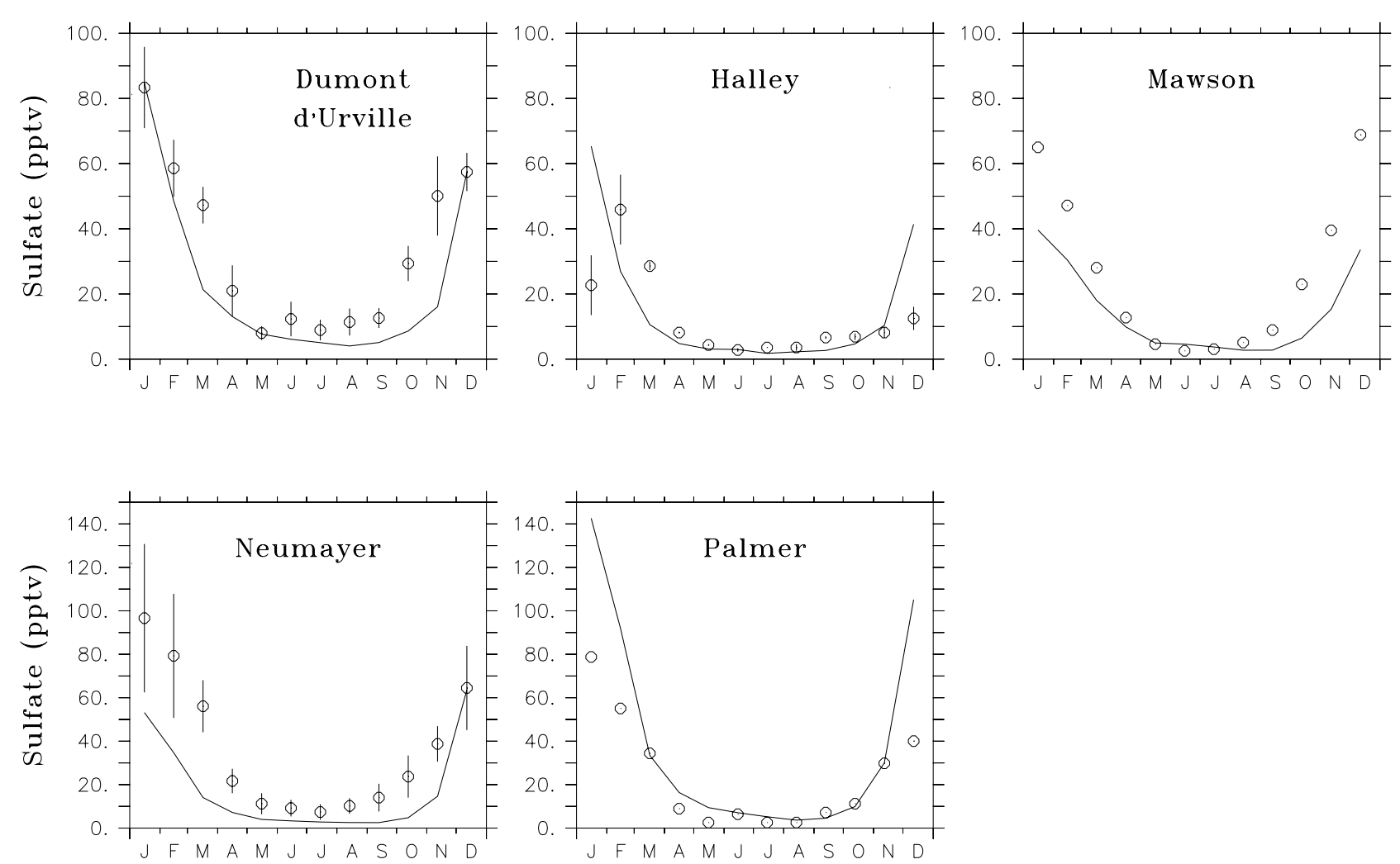

Figure 6. Seasonal variations of nss sulfate (pptv) near the ground at the Antarctic stations Dumontd'Urville $\left(140^{\circ} 1^{\prime} \mathrm{E}, 66^{\circ} 40^{\prime} \mathrm{S}\right)$, Halley $\left(26^{\circ} 19^{\prime} \mathrm{W}, 75^{\circ} 35^{\prime} \mathrm{S}\right)$, Neumayer $\left(8^{\circ} 15^{\prime} \mathrm{W}, 70^{\circ} 39^{\prime} \mathrm{S}\right)$ [Minikin et al., 1998], Palmer $\left(64^{\circ} 03^{\prime} \mathrm{W}, 64^{\circ} 46^{\prime} \mathrm{S}\right)$, and Mawson $\left(62^{\circ} 30^{\prime} \mathrm{E}, 67^{\circ} 36^{\prime} \mathrm{S}\right)$. Open circles represent monthly mean observed concentrations [Minikin et al., 1998; Savoie et al., 1993]. Standard deviations of monthly values (representing year-to-year variability) are plotted as vertical lines. Model results are shown as solid lines.
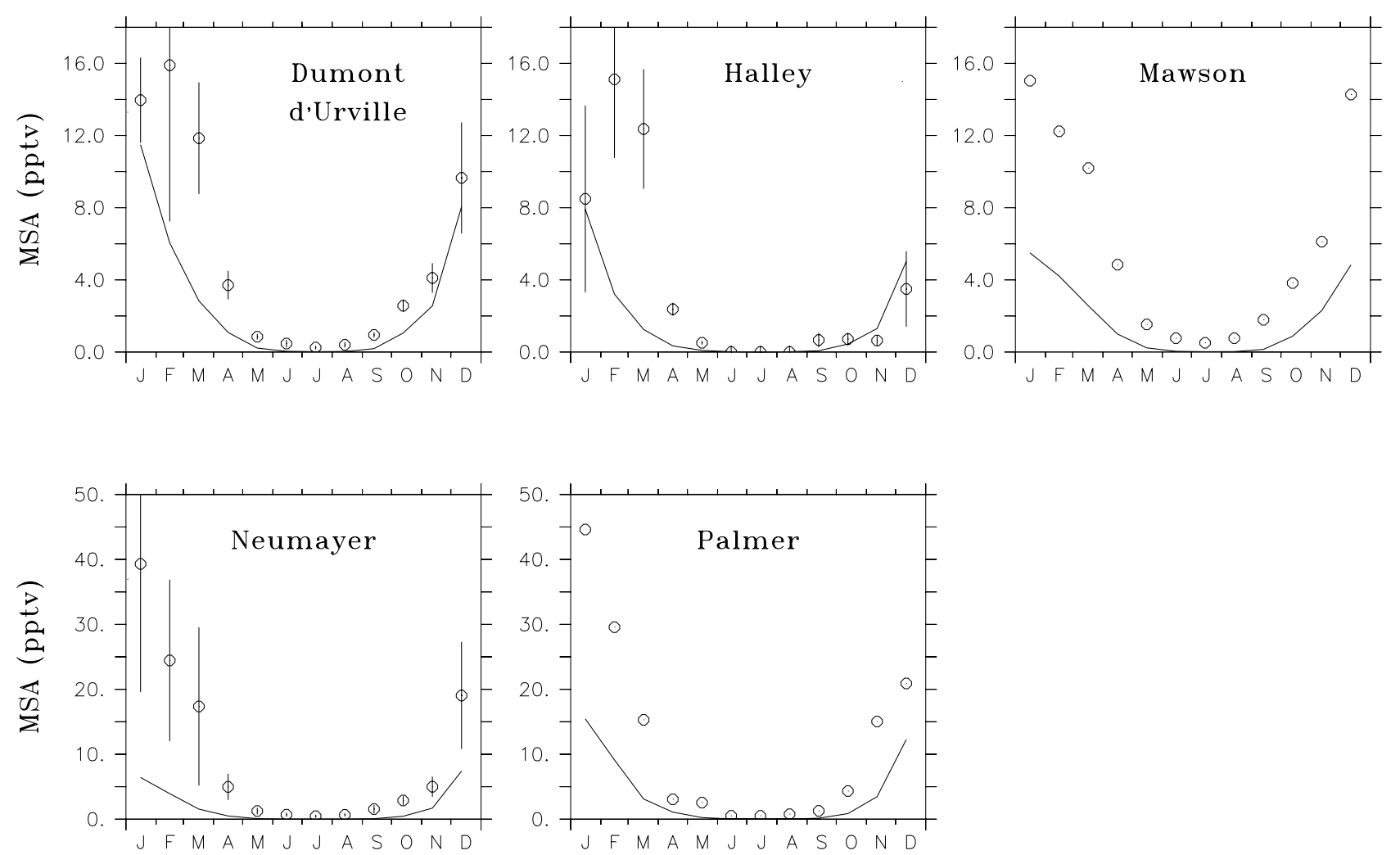

Figure 7. Same as Figure 6 for MSA. 
Table 3. Mean Atmospheric Concentrations, Accumulation Rates, Deposition Fluxes, and Snow Concentrations of NSS Sulfate and MSA at the South Pole

\begin{tabular}{|c|c|c|c|c|}
\hline Source & $\begin{array}{c}\text { Atm. } \\
\left(\mathrm{ng} \mathrm{m}^{-3}\right) \\
\end{array}$ & $\begin{array}{c}\text { Acc. rate } \\
\left(\mathrm{g} \mathrm{cm}^{-2} \mathrm{yr}^{-1}\right) \\
\end{array}$ & $\begin{array}{c}\text { Dep. flux } \\
\left(\mu \mathrm{mol} \mathrm{m} \mathrm{m}^{-2} \mathrm{~d}^{-1}\right)\end{array}$ & $\begin{array}{c}\text { Snow conc. } \\
\left(n g \mathrm{~g}^{-1}\right)\end{array}$ \\
\hline \multicolumn{5}{|l|}{ Nss sulfate } \\
\hline LMD-ZT & 22 & 5.4 & 0.17 & 98 \\
\hline LMD-ZT & 40 (summer) & & & \\
\hline $\mathrm{a}$ & $\sim 100$ & 7.2 & 0.2 & 92 \\
\hline $\mathrm{b}$ & 83 & & & \\
\hline c & $\sim 140$ & & & \\
\hline d & & 8.5 & 0.15 & 70 \\
\hline e & 212 (summer) & & & \\
\hline \multicolumn{5}{|l|}{ MSA } \\
\hline LMD-ZT & 7 (summer) & 5.4 & 0.02 & 13 \\
\hline d & & 8.5 & 0.02 & 8 \\
\hline $\mathrm{e}$ & 12 (summer) & & & \\
\hline
\end{tabular}

LMD-ZT refers to the results of the present study.

${ }^{\mathrm{a}}$ Harder et al. [2000].

${ }^{\mathrm{b}}$ Tuncel et al. [1989].

${ }^{\mathrm{c} C u n n i n g h a m}$ and Waddington [1993].

${ }^{\mathrm{d}}$ From the compilation of Minikin et al. [1998].

${ }^{\mathrm{e}}$ Arimoto et al. [2001].

that other local processes, such as dynamics and deposition, may well be involved in the discrepancy. Some observations of the aerosols vertical distribution in the inland Antarctic atmosphere would be essential to better evaluate the models and to better interpret surface measurements in terms of bulk atmospheric concentrations.

\section{NSS Sulfate and MSA in Antarctic Snow}

[22] Ice core records of nss sulfate and MSA provide a way to reconstruct past atmospheric signals. To establish the air-snow transfer function, the deposition processes must be well understood. In this section, the modeled deposition fluxes and the derived concentrations in snow of nss sulfate and MSA aerosols are compared with observational data. At South Pole, in addition to accumulation rates and snow concentrations, some measurements of ground-level atmospheric concentrations of MSA and nss sulfate have been carried out [Tuncel et al., 1989; Cunningham and Waddington, 1993; Harder et al., 2000; Arimoto et al., 2001] (Table $3)$. The atmospheric concentrations are underestimated by the model, as already discussed in section 3.3. In spite of that, and in spite of a slight underestimation of the accumulation rate, the simulation displays very good deposition fluxes and reasonable, although somewhat high, snow concentrations for both species. At three Antarctic coastal stations [Wolff et al., 1998a], surface atmospheric measurements have been carried out simultaneously with measurements in fresh snow. Scavenging ratios have been calculated following:

$$
W=\rho_{\text {air }} \frac{C_{s}}{C_{\text {air }}}
$$

where $W$ is the scavenging ratio, $\rho_{\text {air }}$ is the air density, and $C_{S}$ and $C_{\text {air }}$ are the concentrations of the species in snow and air, respectively. Although not highly meaningful [Wolff et al., 1998a], the scavenging ratio is, from surface data only, the best available concept that characterizes the rate of wet deposition, which largely dominates over the other deposition processes in the coastal regions. Table 4 shows that the model systematically overestimates the scavenging ratios. Thus, model results at the South Pole and at the coastal stations consistently suggest excessive deposition in the model.

[23] This systematic bias is confirmed by data at 30 Antarctic sites (Figure 8) where snow accumulation rates, concentrations of MSA and nss sulfate in firn and ice cores have been measured [Minikin et al., 1998]. Accumulation rates, shown on Figure 9, are fairly well simulated, with a correlation factor of 0.89 between field data and model results. This confirms the ability of the model to capture the major patterns of Antarctic precipitation [Krinner et al., 1997; Genthon and Krinner, 2001]. On Figure 10, the modeled concentrations in snow and deposition fluxes are, respectively, compared with observed concentrations in snow, and fluxes deduced from observed concentrations in snow and accumulation rates [Minikin et al., 1998]. Sites 16-19 do not provide data for MSA.

[24] Simulated concentrations in snow are almost systematically larger than measured concentrations, and the correlations are rather poor $(0.37$ and 0.65 for MSA and nss sulfate, respectively), in spite of better correlations for deposition fluxes (0.76 and 0.84$)$. Indeed, snow concentrations cumulate errors in both simulated accumulation and deposition. Simulated deposition fluxes of MSA and nss sulfate correlate rather well with observation-derived fluxes. However, most of deposition fluxes of nss sulfate and MSA are overestimated. In particular, modeled nss sulfate fluxes are often twice higher than observed ones. These overestimations are due to an excessive wet deposition. Indeed, dry/wet deposition ratio never exceeds 0.15 , except for interior sites (numbers 11-14 and 19), and wet deposition fluxes alone remain larger in the simulation than deposition fluxes in the observations for most of the sites. Moreover, simulated wet deposition from in-cloud scavenging is at least 20 times larger than deposition from below-cloud scavenging near the coast, and generally more than 20 times larger inside the continent. Boucher et al. [2002] stress that incloud scavenging scheme of our model is the same for liquid and solid precipitation, and the present results illustrate the limit of such an approximation. Snow precipitation should be distinguished from rain in further studies.

\section{Previous Modeling Studies}

[25] Some previous 3D studies of the sulfur cycle [Langner and Rodhe, 1991; Pham et al., 1995; Chin et al., 1996, 2000; Roelofs et al., 1998; Barth et al., 2000] or of atmospheric DMS [Sciare et al., 2000b] refer to obser-

Table 4. Observed [Wolff et al., 1998a] and Modeled Scavenging Ratios of MSA at Dumont d'Urville, Neumayer, and Halley and Sulfate at Neumayer and Halley

\begin{tabular}{lcc}
\hline & Observed & Modeled \\
\hline MSA Dumont d'Urville & 1600 & 2300 \\
MSA Neumayer & 800 & 3300 \\
Sulfate Neumayer & 950 & 3000 \\
MSA Halley & 3100 & 4100 \\
Sulfate Halley & 3300 & 4000 \\
\hline
\end{tabular}




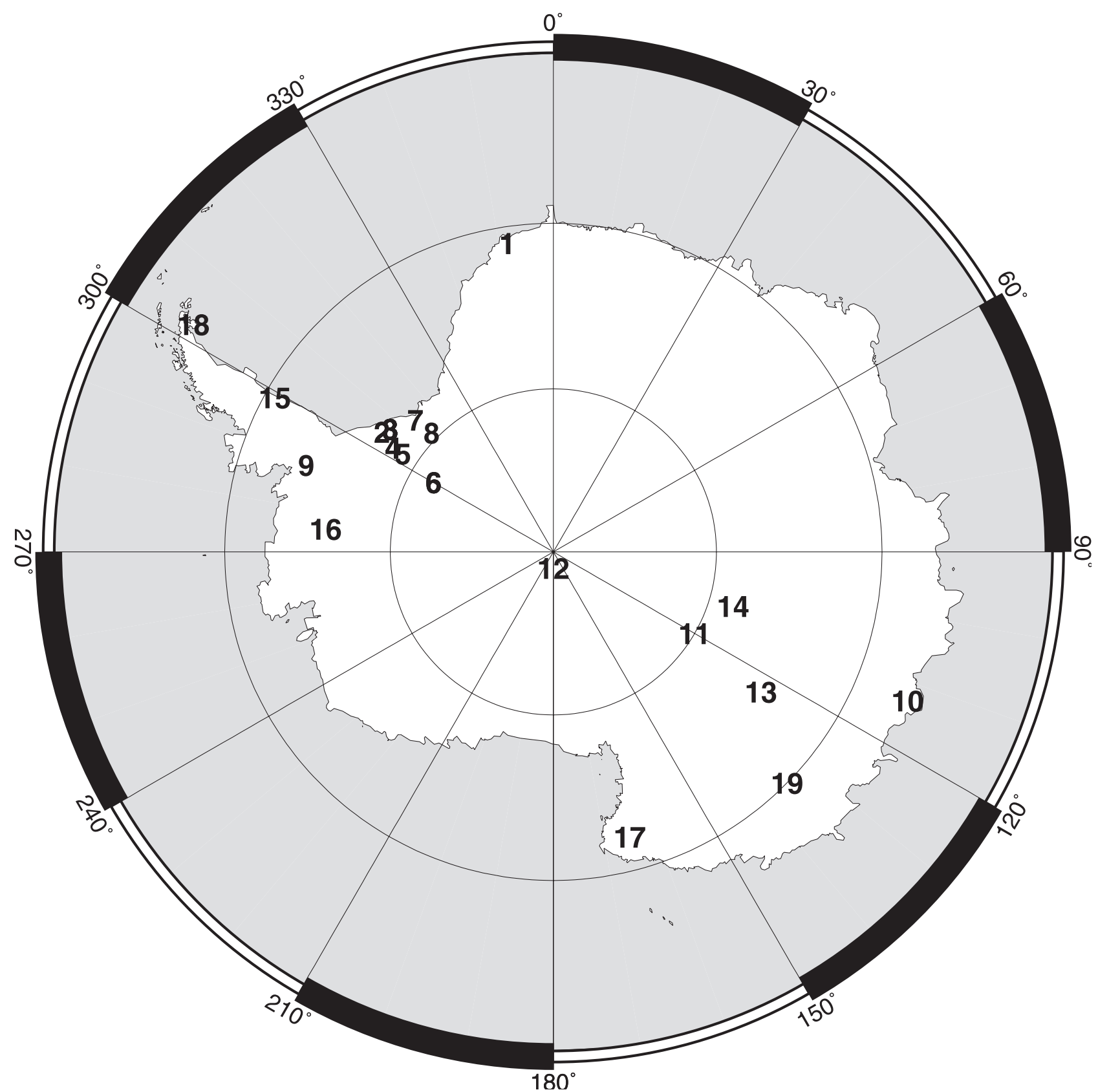

Figure 8. Antarctic sites considered in the present study, from the data compiled by Minikin et al. [1998]. The sites belonging to the same model grid box are gathered together and their snow concentrations and deposition fluxes are averaged.

vations at middle- and high-southern latitudes to evaluate the models behavior in remote marine regions. Comparing our results with other studies may help evaluating our model, and identifying systematic model biases and their origin. Most previous 3D studies cited above make use of oceanic DMS emissions derived by Bates et al. [1987] or Bates et al. [1992b]. The global distribution in both data sets is an extrapolation of studies performed in the northern Pacific. Oceanic DMS concentrations and the derived seaair fluxes are meridional averages, although Bates et al. [1987] consider a zonal variation in the equatorial region and treat the coastal regions separately. Two seasons are considered for the temporal variations. Langner and Rodhe
[1991] directly use the emission fluxes of Bates et al. [1987]. Chin et al. [1996] apply the parameterization of sea-air flux of Tans et al. [1990] onto the oceanic DMS concentrations of Bates et al. [1987]. Roelofs et al. [1998] and Barth et al. [2000] postprocess the data of Bates et al. [1992b], distributing DMS emissions across the latitude bands using pigment concentrations from the Coastal Zone Color Scanner, following the method of Benkovitz et al. [1994]. Pham et al. [1995] calculate sea-air DMS flux by distributing a global flux of $19.2{\mathrm{TgS} \mathrm{yr}^{-1}}^{-1}$ following the solar flux intensity at the ocean surface. In all these studies, the seasonal cycle of DMS at Amsterdam Island and Cape Grim is less marked than the one observed (Figure 3). It is 


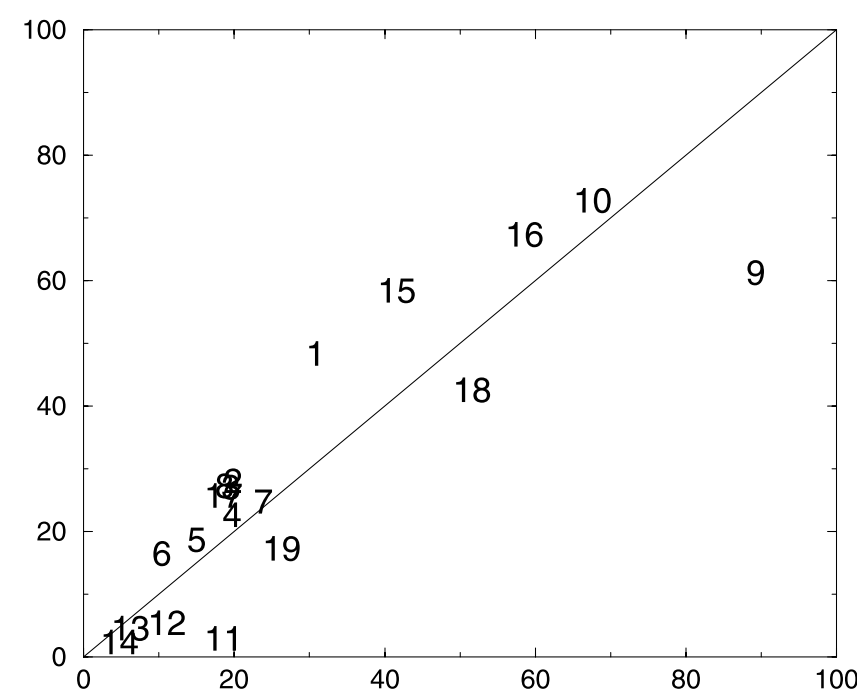

Figure 9. Scatterplots of measured versus modeled accumulation rates $\left(\mathrm{g} \mathrm{cm}^{-2} \mathrm{yr}^{-1}\right)$ at the Antarctic sites shown on Figure 8. Experimental data are drawn from the compilation of Minikin et al. [1998].

also the case for nss sulfate at the Antarctic stations Mawson and Palmer, where fall, winter, and spring concentrations are overestimated most of the time, except in the study by Chin et al. [1996]. The authors generally link this systematic bias to insufficient seasonal variations of oceanic emission fluxes of DMS. Chin et al. [1996] overestimate nss sulfate concentrations all year-round at Palmer and in summer and fall at Mawson. This may be related to the parameterization of sea-air transfer of Tans et al. [1990] that yields larger fluxes than the scheme of Liss and Merlivat [1986] [Erickson, 1993]. Indeed, Chin et al. [1996] obtain the highest global oceanic flux of DMS of

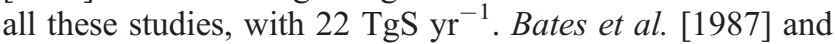
Pham et al. [1995] mention the possibly high emission fluxes of DMS in regions where phytoplanktonic blooms frequently occur and winds are strong, such as the Antarctic region, but their emission estimates do not take into account this "biological" factor.

[26] On the other hand, Chin et al. [2000] and Sciare et al. [2000b] make use of the more recent global database of oceanic DMS concentrations of Kettle et al. [1999], which takes into account sparse measurements at middle- and high-southern latitudes. As in our study, DMS emissions are computed from this database and sea-air fluxes calculated with the parameterization of Liss and Merlivat [1986]. However, different wind fields are used in the three studies. Sciare et al. [2000b] reproduce a well marked DMS seasonal cycle at Amsterdam Island, although TM3 model, used in this study, tends to slightly overestimate DMS concentrations. The GOCART model [Chin et al., 2000] captures the seasonality of DMS at Cape Grim, but leads to low summer values at Amsterdam Island. It is noticeable that the GOCART model overestimates summer concentrations of nss sulfate at Palmer, underestimates them at Mawson, and reproduces good concentrations in fall and winter, as observed for LMD-ZT (section 3.3). Because the models that use other sources than those of Kettle et al. [1999] never show these particular features, we can hypothesize that it is due to the sources. Oceanic DMS concentrations of Kettle et al. [1999] may be somewhat overestimated in summer in the region of Palmer, and underestimated in the region of Mawson.

[27] The GOCART model also reproduces the seasonal variations of MSA at these Antarctic stations, whereas LMD-ZT underestimates them virtually systematically. We suggested in section 3.3 that it was linked to an insufficient oxidation of DMSO. DMSO is not taken into account in the GOCART model, thus MSA is directly formed by DMS oxidation. The result of Chin et al. [2000] thus provides another evidence of a missing DMSO sink in LMD-ZT, as advanced in section 3.2 .

[28] These brief comparisons show that LMD-ZT is among the best models for representing the sulfur cycle at middleand high-southern latitudes. Moreover, our results strongly suggest that emission fluxes of DMS, through their spatial and temporal variability, play a major role in the modeled concentrations of sulfur compounds in these regions.

\section{Modeled Versus Observed Variability}

[29] For all sulfur species, a mean seasonal cycle, which is to a large extent driven by the DMS source, is reproduced by the model. In this section, we evaluate the model ability to reproduce realistic variability at subseasonal (monthly) and interannual timescales. Figure 11 shows time series of observed and simulated atmospheric nss sulfate at Dumont d'Urville over the 1995-1999 period. Sulfate is, with MSA, the only sulfur species that was monitored over the full period covered by the simulation. The interannual variability of peak summer concentration is high, both in the observations and in the model. However, in spite of a strong control of the circumpolar atmospheric circulation through nudging with meteorological analyses, the model shows little common (correlated) variability with the observations. Thus, according to the model, the interannual variability of sulfate cannot be interpreted in terms of variability of resolved atmospheric circulation and transport only. It has been verified (but not shown here) that this is also the case at other sites in Antarctica.

[30] Figure 11 suggests that variability is roughly one order of magnitude smaller in winter than in summer. However, mean concentrations are also, on average, about one order of magnitude smaller in winter than in summer. Therefore, although small in absolute terms, winter variability is very significant relative to mean winter concentrations. To provide a synthetic picture of relative variability at all months and seasons, series of monthly relative anomaly $\Delta C$ are constructed, after seasonal detrending, by scaling the monthly deviation by the interannual mean concentration for each month:

$$
\Delta C(m, y)=100 \cdot \frac{C(m, y)-\bar{C}(m)}{\bar{C}(m)}
$$

where $C(m, y)$ is the observed or modeled mean concentration for month $m$ and year $y$, and $\bar{C}(m)=\Sigma_{y=95}^{99} C(m, y) / 5$ is the interannual mean concentration for month $m$. A 100 multiplier is used to obtain anomalies in \%.

[31] Figure 12 compares $\Delta C$ for observed and modeled nss sulfate at Dumont d'Urville. There is virtually no 

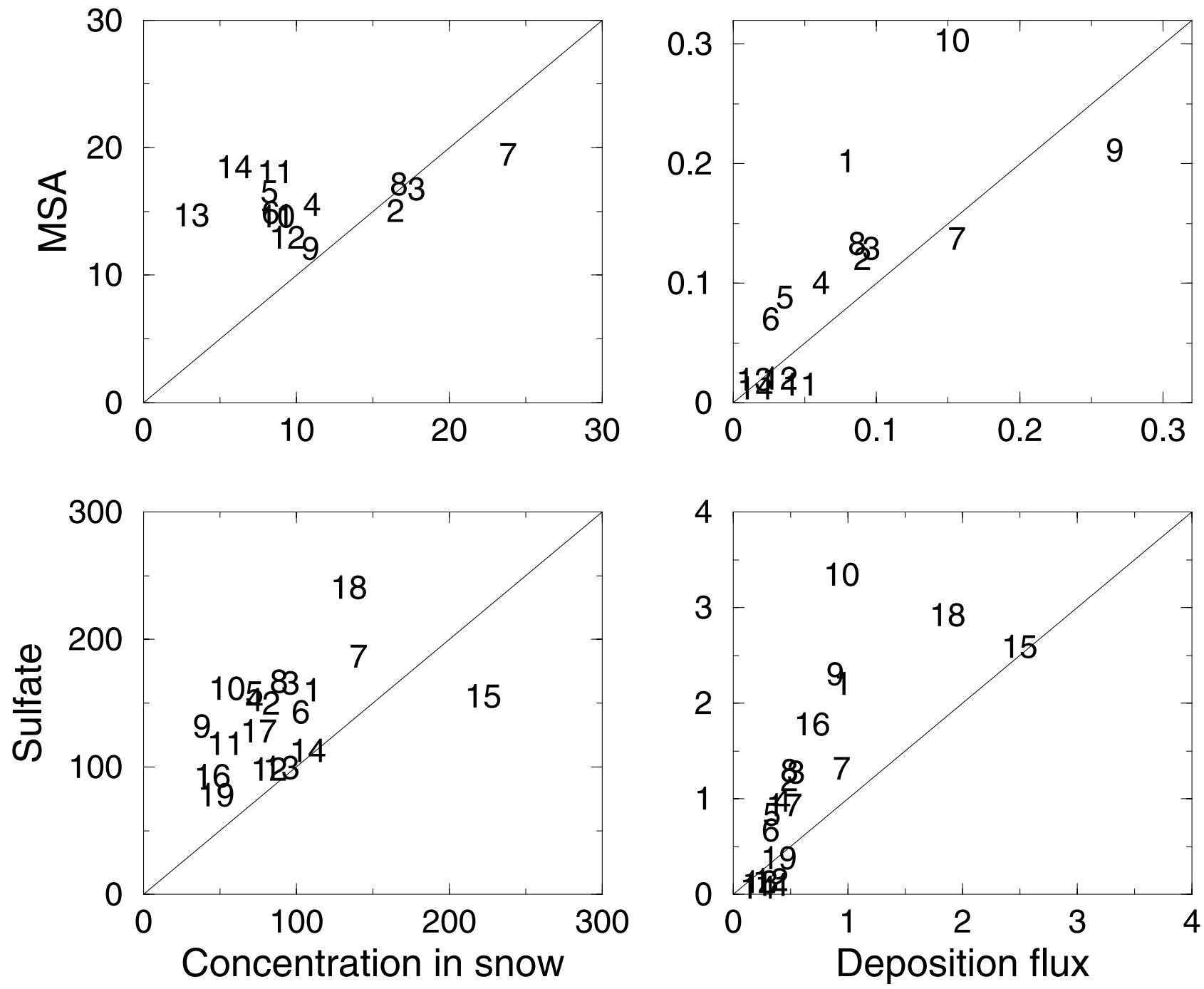

Figure 10. Scatterplots of measured versus modeled concentrations in firn and ice cores (ng $\mathrm{g}^{-1}$ ) and deposition fluxes ( $\mu \mathrm{mol} \mathrm{m} \mathrm{m}^{-2} \mathrm{~d}^{-1}$ ) of MSA (upper row) and nss sulfate (lower row) at the Antarctic sites shown on Figure 8. Experimental data are drawn from the compilation of Minikin et al. [1998]. MSA at site 15 is off-scale and not plotted.

correlation between the 2 series. This is, again, in spite of forcing the large-scale circulation of the model toward that of the real world. In addition, the standard deviation of the relative anomaly is almost twice larger in the observations than in the model, suggesting again a missing source of variability.

[32] Because the mean levels and seasonality are relatively well reproduced, a major deficiency of the model atmospheric physics and/or chemistry modules is not a likely explanation for this failure. There are several other possible reasons though. In particular, in spite of using a high-resolution grid over Antarctica, the simulated meteorological and chemical features are meaningful as averages on scales of $\sim 10^{4} \mathrm{~km}^{2}$. The observations may have a much more local significance, particularly because a marked land/ ocean contrast affects horizontal homogeneity at the coastal stations. Observations inland of Antarctica are too scarce for an evaluation of variability and comparison with model results. On the other hand, at lower latitudes, Amsterdam Island possibly offers a more homogeneous environment than Dumont d'Urville. In addition, relatively long series of the main sulfur precursor, DMS, are available from observation. Figure 13 compares, over their common period of availability, the observation and simulation of the surface DMS mixing ratio at Amsterdam Island and shows that, again, variability differs markedly. This is confirmed by the comparison of monthly relative anomalies, and a similar conclusion was reached by Sciare et al. [2000b], using the chemistry-transport model TM3. Our model systematically displays a triple peak in summer, which is not confirmed by the observations. Figure 3 indicates that this is a consequence of the regional DMS source flux. Variability is thus spuriously introduced in the model through the prescription of a source flux [Kettle et al., 1999] which is clearly inappropriate for the period of interest.

[33] On the other hand, simulated DMS at Dumont d'Urville has a shoulder in April-May which bears some similarity with a (austral) fall secondary peak in the observations (Figure 2). Examination of the DMS source, either locally at Dumont d'Urville or at wider scales, excludes that 


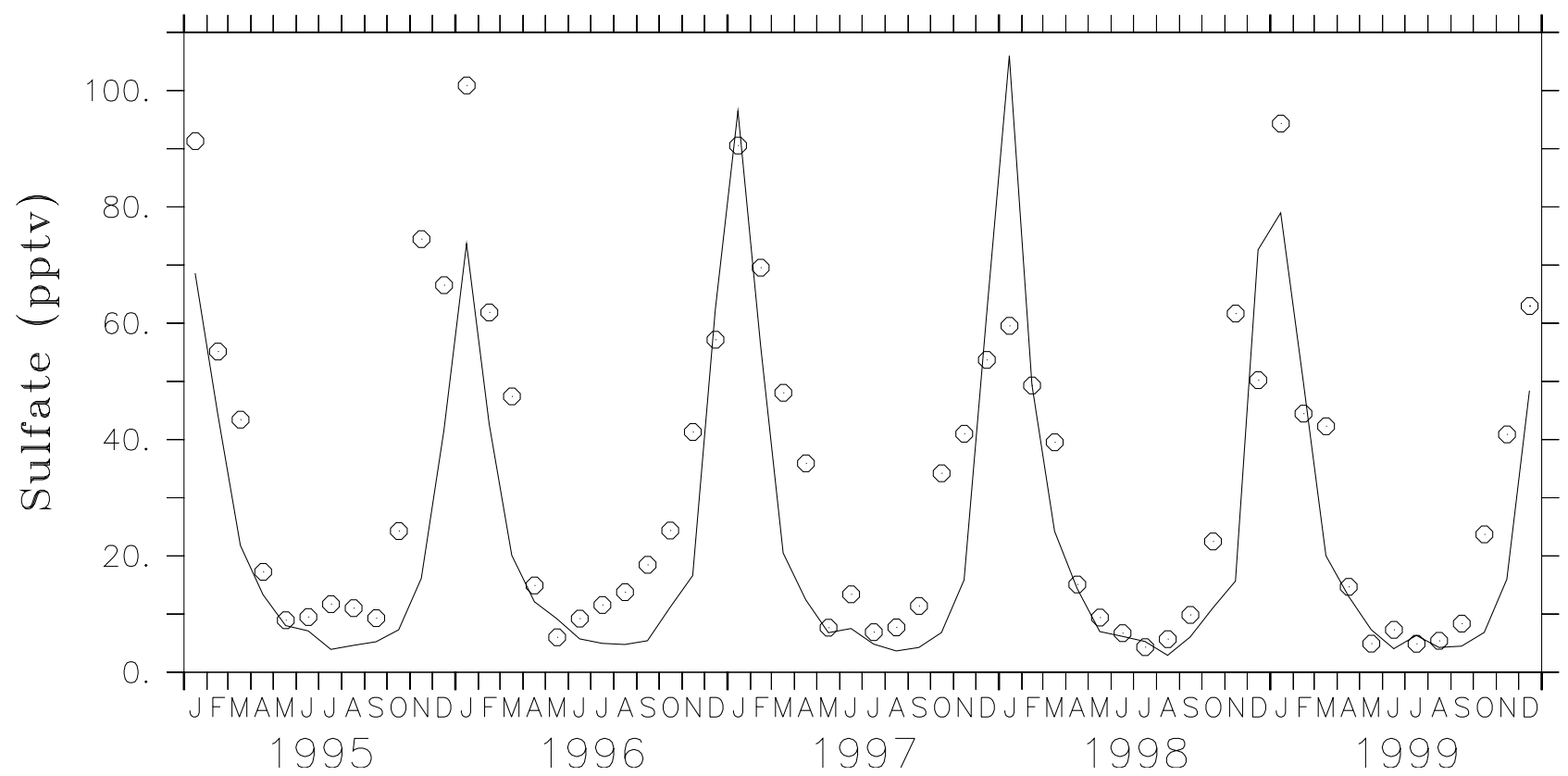

Figure 11. The nss sulfate mixing ratio at Dumont d'Urville over the 1995-1999 period. Observations are symbolized by circles and simulated values by the solid line.

this is a result of the prescribed oceanic fluxes. Therefore, in spite of resolution limitations, the internal model physics and/or chemistry is able to reproduce some prominent features of the observed variability of coastal DMS.

[34] Yet, a large fraction of the observed variability, including within and beyond seasonality, has most probably its origin in the source of DMS, and a prescribed source with no interannual variability is obviously a strong limitation. In addition, there are very few direct observations of
DMS concentration at high-southern latitudes, and even the mean seasonal variance is questionable. Using the Chemistry-Transport Model TM3, Sciare et al. [2000b] already found the variability of meteorological parameters insufficient for explaining the variability of atmospheric concentrations of DMS at Amsterdam Island. However, Antarctica features, with sea ice cover, an extra meteorological parameter likely to affect DMS emissions. Experiments to assess the model sensitivity to various changes and tentative

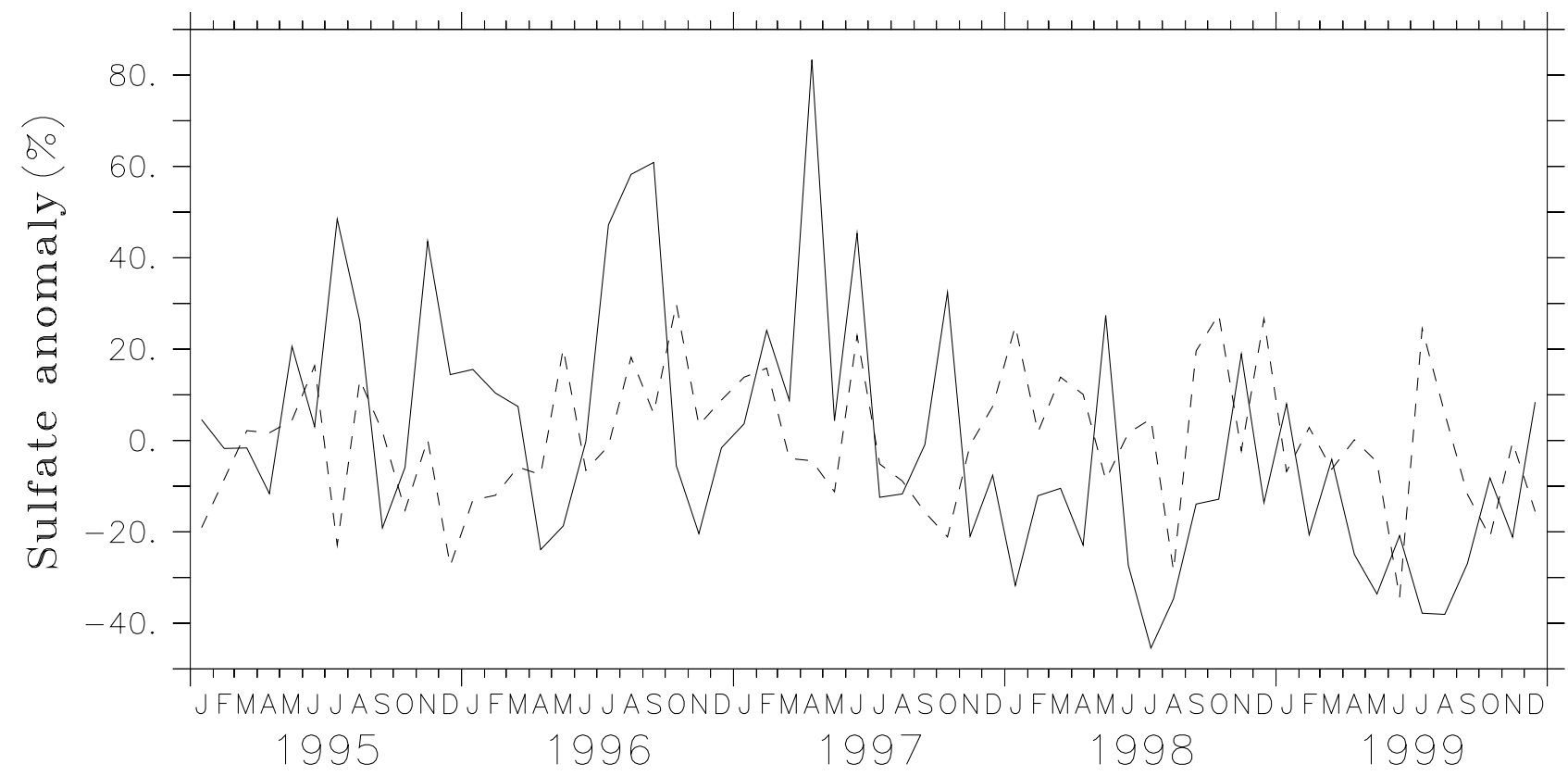

Figure 12. Monthly relative anomaly (defined in text) of nss sulfate at Dumont d'Urville (in \%). Observations are symbolized by the solid line and simulated values are symbolized by the dashed line. 


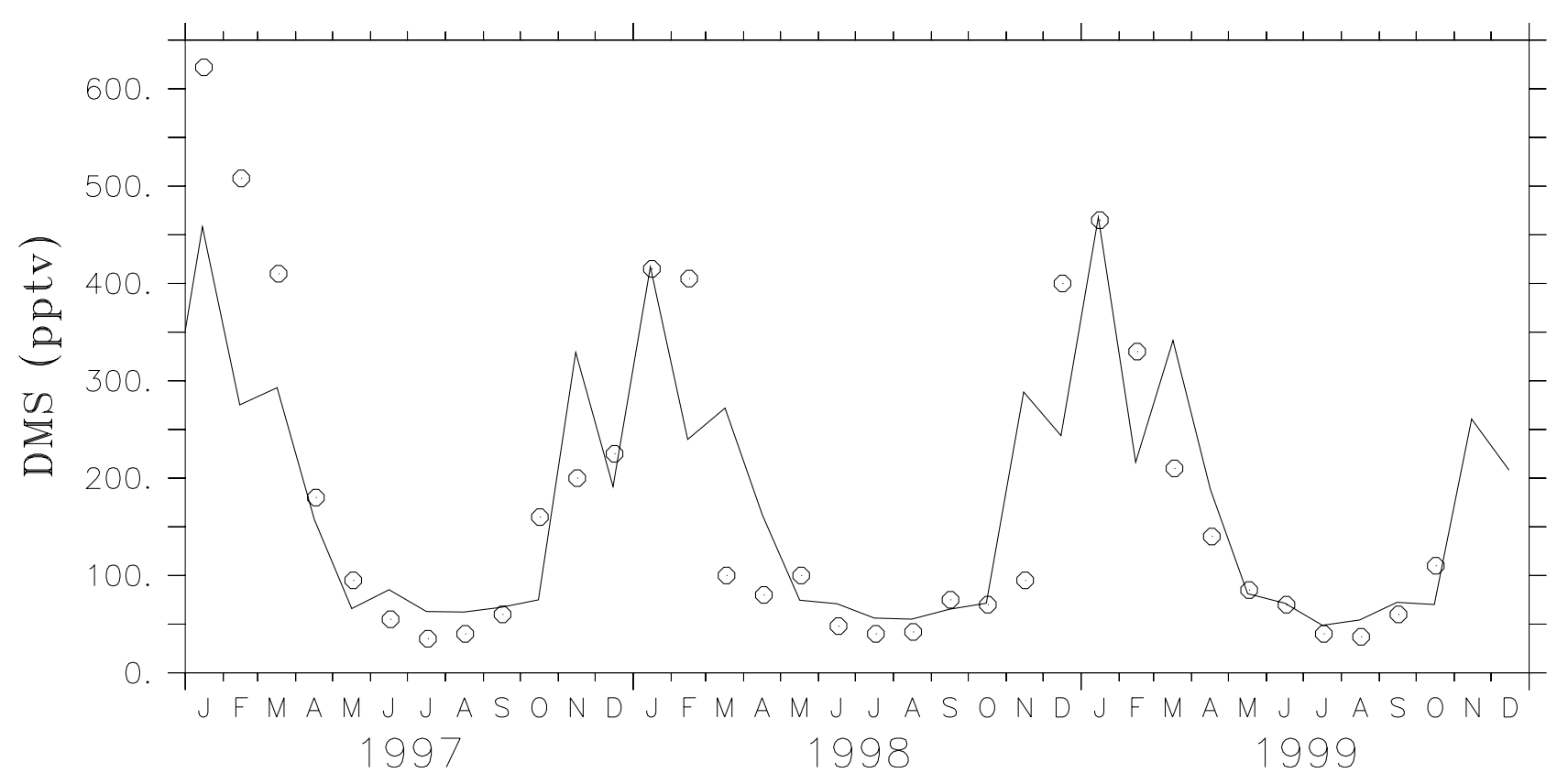

Figure 13. DMS mixing ratio at Amsterdam Island over the 1997-1999 period. Observations are symbolized by circles and simulated values are symbolized by the solid line.

improvements of the source formulations, including interannual variability, are presented in section 7 .

\section{A Test on Oceanic Sources of DMS}

[35] The sulfur cycle in Antarctica is mainly driven by oceanic sources of DMS around the continent. Rather few measurements of DMS concentrations in oceanic surface waters have been performed at high-southern latitudes [Bates et al., 1987; Andreae, 1990; Turner et al., 1995; Kettle et al., 1999]. Moreover, the role of sea ice on DMS emissions is still unclear [Levasseur et al., 1994; Curran, 1996; Curran and Jones, 2000]. The presence of sea ice seems to affect strongly DMS concentrations in surface water [Curran et al., 1998]. In particular, open water holes in sea ice, like polynyas, can have a large impact on the local atmospheric DMS load [e.g., Kleefeld, 1998]. Sea ice by itself can also shelter the blooming of algae communities [Hoshiai, 1985], producing high levels of dimethylsulfoniopropionate (DMSP), the precursor of DMS [Kirst et al., 1991; Levasseur et al., 1994; Turner et al., 1995]. DMS is then released in the atmosphere when sea ice breaks or melts. At the same time, ice algae released in the water initiate phytoplanktonic blooms, and consequently high concentrations of DMS in the surface water. Because the processes involved are still insufficiently known, the influence of sea ice cover onto intensity and temporal variability of DMS emissions is poorly quantified, and rarely taken into account in global database processing or in global models.

[36] As a sensitivity test of the impact of sea ice conditions on DMS fluxes around the Antarctic coast, we have performed two simulations, in which DMS fluxes are computed on-line using the DMS seawater concentration maps of Kettle et al. [1999] and the method of Liss and Merlivat [1986] with the wind and surface temperature fields of the model (sea surface temperature is prescribed). In the first simulation, sea ice conditions are not taken into account at all, so that regions covered by ice can display nonzero concentrations. In the second simulation, the seato-air flux in a grid mesh is linearly related to the fraction of open ocean. The sea ice fraction is prescribed from satellite data, with realistic subannual and interannual variability. The simulations have been run over 3 years (1997-1999). The test simulations only differ by the role given to sea ice in DMS fluxes. The differences between the results of the two test simulations illustrate the role of sea ice as a mask of the sea-air interface, canceling DMS emissions.

\subsection{Impact of Sea Ice on Atmospheric DMS}

[37] Emissions south of $60^{\circ} \mathrm{S}$ obtained in the two test simulations are larger than in the reference simulation (1.76 and 1.21 versus $0.96 \mathrm{TgS} \mathrm{yr}^{-1}$ ) and the global fluxes follow the same trend (22.09 and 21.25 versus $\left.19.43 \mathrm{TgS} \mathrm{yr}^{-1}\right)$. Even if the fluxes in the reference simulation were computed with climatological wind speed and SST fields independent of our model, this result primarily agrees with the recent work of Chapman et al. [2002], which demonstrates that the use of time-averaged wind speeds, in comparison with model time step wind speeds, leads to lower flux estimates. A significant part of the difference between the global sulfur emissions in the 3 simulations comes from the polar regions.

[38] The impact of sea ice on the atmospheric DMS surface concentrations can be seen on Figure 14, which represents the ratios (in \%) of DMS surface mixing ratios of the second to the first test simulation in January and in July. The coastal regions of Antarctica are most affected, displaying the lowest values, down to $20 \%$ and sometimes less in July. At the Antarctic coastal stations considered in this paper (see Figure 1), this ratio rarely exceeds 50\% and 


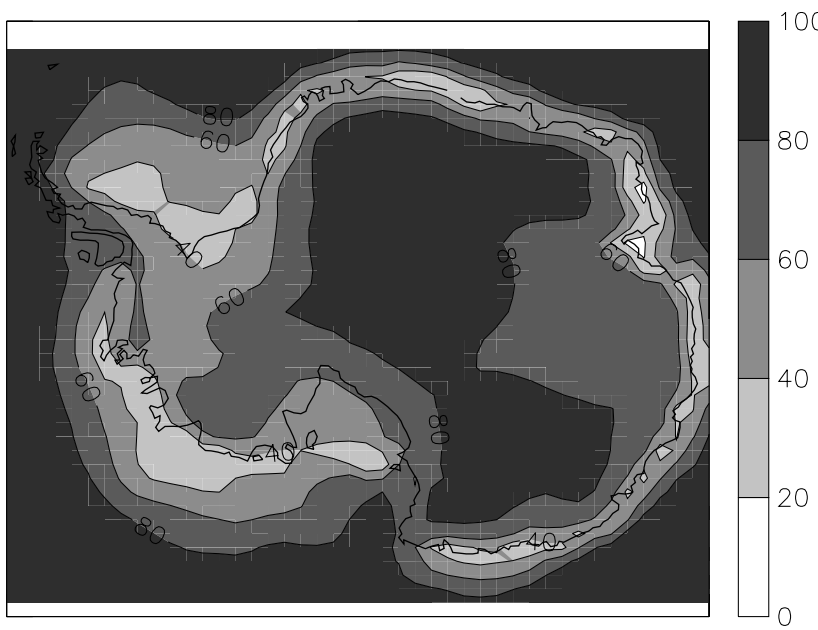

(a)

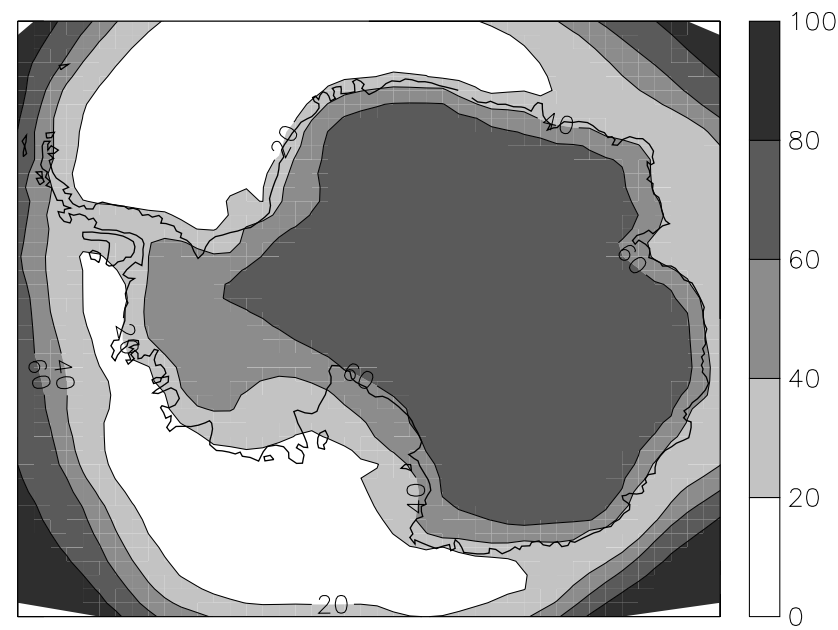

(b)

Figure 14. Ratios (in \%) of surface DMS concentrations of the second to the first sensitivity experiment on DMS sources in (a) January and (b) July.

reaches $6 \%$ at Mawson. Thus, the atmospheric DMS mixing ratios at the coast can vary by a factor of about 5 or more due to the effect of sea ice. Wintertime DMS concentrations measured at Dumont d'Urville in 1999 are about 2 and 5 times larger than those measured during 2000 and 2001 respectively (Figure 2) [Jourdain, 2001]. Jourdain and Legrand [2001] suggested that these high levels could be related to anomalously low sea ice cover around the station in March-April 1999. However, the first test simulation, with no impact of sea ice on DMS emissions, leads to DMS concentrations lower than those observed at Dumont d'Urville in winter 1999. We should note that our test simulations do not take into account potentially enhanced DMS emissions in fractional sea ice areas. In addition, at the relatively large scale of the model grid, the sea ice clima- tology does not show any anomaly around Dumont d'Urville in 1999.

\subsection{Temporal Variability}

[39] Although the model does not fully capture the observed interannual variations of the sulfur cycle, our test simulations may enhance the variability of the results (as defined in (1)) to more realistic values. As in section 6, the monthly relative anomalies of nss sulfate at Dumont d'Urville were calculated (Figure 15). Standard deviations of $13.9 \%$ and $16.4 \%$ are obtained for the first and second test simulations respectfully. Thus, the lid effect of sea ice enhances the variability of nss sulfate concentrations. However, the modeled variability remains weaker than the observed one at $26.2 \%$.

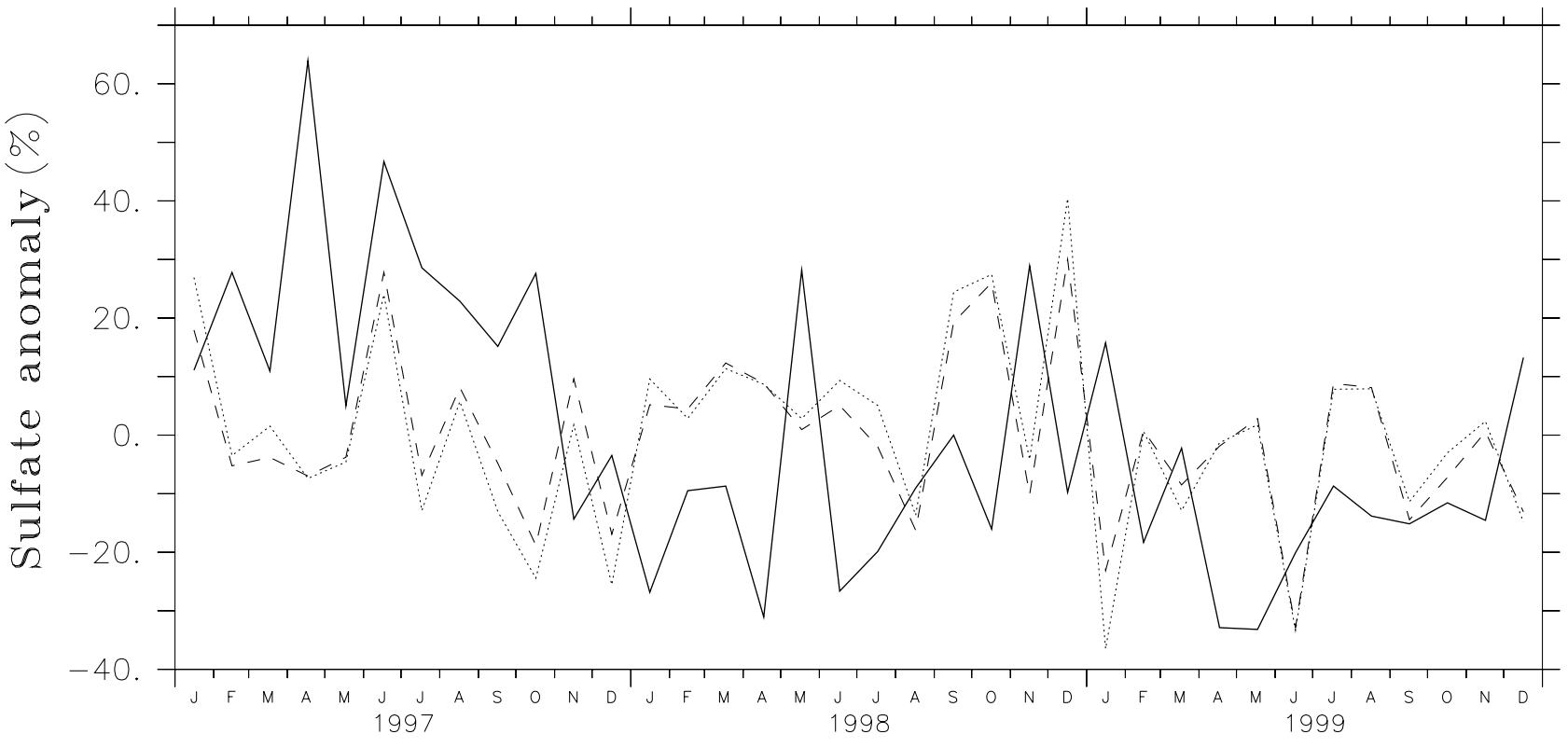

Figure 15. Monthly relative anomaly (in \%) of nss sulfate at Dumont d'Urville, calculated from observations (solid line) and sensitivity experiment on DMS sources 1 (dashed line) and 2 (dotted line). 


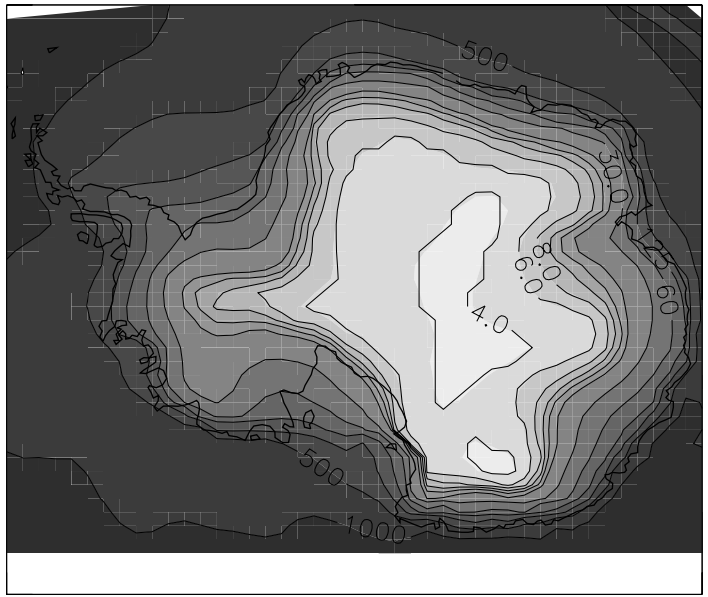

(a)

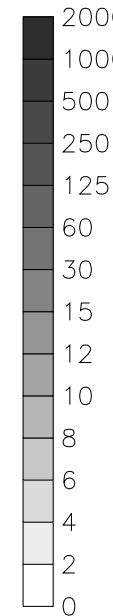

)

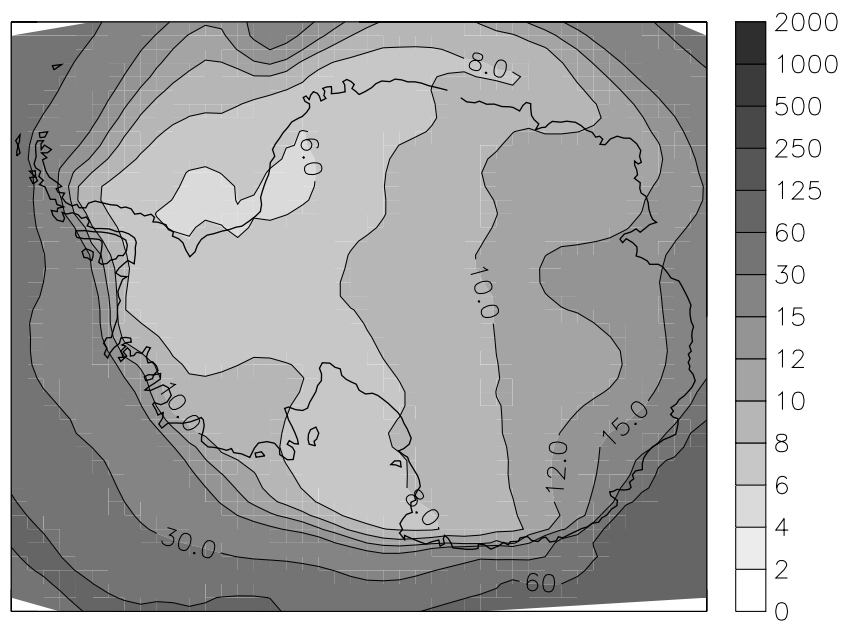

(b)

Figure 16. Simulated DMS surface mixing ratios (pptv) over Antarctica in (a) January and (b) July.

[40] Although at first order, seasonal variations of nss sulfate are well captured by the model (as shown in Figure $11)$, there is no correlation between modeled and observed monthly anomalies (correlation coefficients of -0.09 and -0.13 are obtained for tests 1 and 2 , respectively). Therefore our efforts to include the effects of year-to-year changes in meteorology and sea ice on DMS emissions lead to spurious enhancements of temporal variability rather than a better modeling of interannual variations of nss sulfate. On the other hand, there is a good correlation between monthly anomalies of the reference simulation and test simulations (c $=0.87$ and $\mathrm{c}=0.82$ for tests 1 and 2 , respectively). This reveals that changes in meteorology and sea ice cover are not the main process that govern variability of sulfur concentrations at the monthly timescale. To obtain realistic temporal variability at this scale, it is then necessary to consider the variability of oceanic concentrations of DMS. Other preliminary test experiments were performed, including arbitrary parameterizations of phytoplanktonic blooms as a function of sea ice melting and drifting, but they remained unsuccessful.

[41] Our results are consistent with the analysis and modeling of interannual variability of DMS at Amsterdam Island by Sciare et al. [2000b]. These authors concluded that year-to-year anomalies could not be explained only by changes in meteorology and/or oxidation capacity of the atmosphere. They found an important correlation between DMS and SST anomalies, and concluded that interannual changes in the ocean DMS concentrations should be the major source of DMS interannual variability at Amsterdam Island. Because we did not find any correlation between observed DMS levels and the SST data we use (GISST data), we did not investigate this possibility through sensitivity experiments in which oceanic DMS concentrations would be linked to SST. Further works could take into account recent satellite-based distribution of sea surface DMS concentrations that feature realistic temporal variability. The build up of these global maps is presently in progress (S. Belviso et al., A new, satellite-based method for estimating global oceanic dimethylsulfide concentrations and its application in a three-dimensional atmospheric general circulation model, in Proceedings of the International Workshop on Emissions of Chemical Species and Aerosols Into the Atmosphere, Paris, France, 19-22 June, edited by C. Granier, submitted, 2001; S. Belviso and C. Moulin, Assessment of a global climatology of oceanic dimethylsulfide (DMS) concentrations based on SeaWIFS imagery (1998-2001), submitted to Deep Sea Research, 2002).

\section{Synthesis of Sulfur Distribution and Budget for the Antarctic Region}

[42] Studies of the global sulfur cycle are often motivated by the climatic effect of aerosols formed at the end of the oxidation chain [Langner and Rodhe, 1991; Taylor and Penner, 1994; Pham et al., 1995; Feichter et al., 1996; Chin et al., 1996; Kasibhatla et al., 1997; Roelofs et al., 1998; Kiehl et al., 2000; Koch et al., 1999]. Polar regions, where concentrations are consistently lower than in the lower latitudes and where the solar flux is weaker, has attracted little attention in the literature. Emblematically, contour or color scales selected for showing global distributions of sulfur species are often inappropriate for characterizing the polar regions. It is therefore rather difficult to compare our results with other model studies at high-southern latitudes, beyond the analysis reported in section 5. Also, there are unfortunately not enough available observations to validate the simulated horizontal and vertical distributions reported here. Thus, we present here material nonavailable from other sources, but containing uncertainties inherent to the model.

\subsection{DMS Distribution}

[43] Figure 16 depicts simulated DMS surface mixing ratios over Antarctica. In summer, and in the coastal regions, the pattern displays a high gradient perpendicular to the coastline. In the center, the minimum reaches about 4 versus $30-500$ pptv at the coast. The gradient is much smoother in winter than in summer. In winter, the minimum is found in the Halley station region, below 6 pptv, and mixing ratios at the coast vary from 4 to $30 \mathrm{pptv}$. Contrary to the coastal regions, the mixing ratios inside the continent 


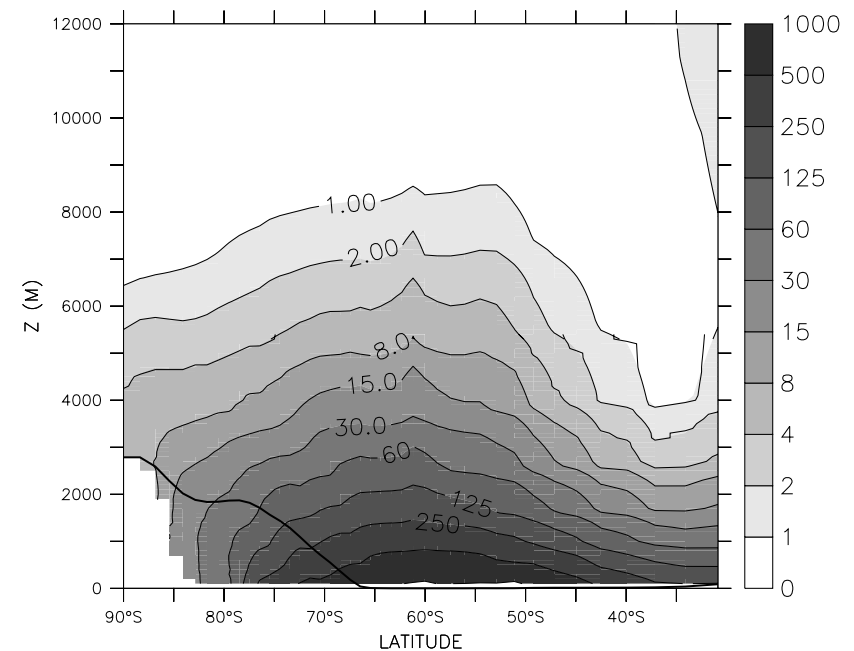

(a)

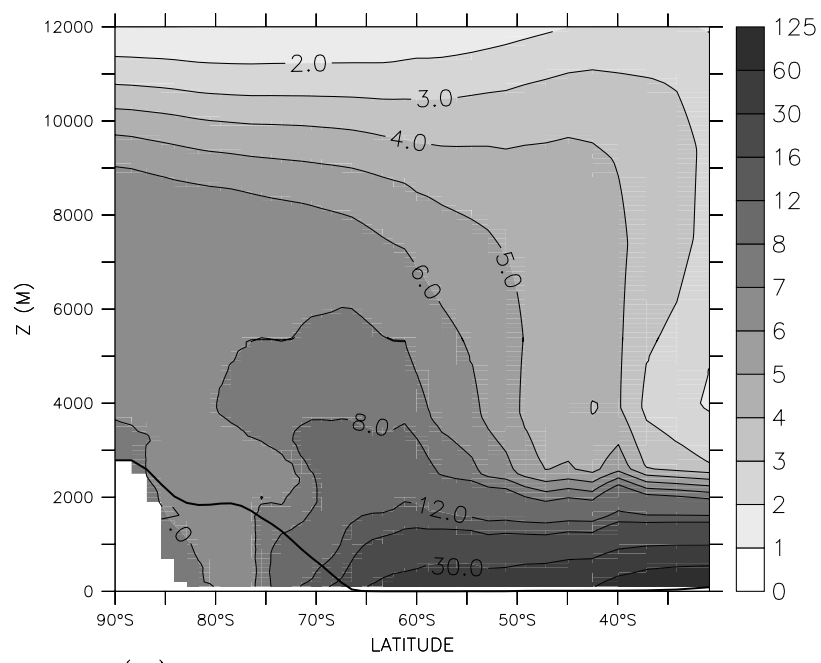

(b)

Figure 17. Zonally averaged simulated DMS mixing ratios (pptv) at middle- and high-southern latitudes in (a) January and (b) July. The thick line represents the mean elevation of the Antarctic ice sheet.

have the same order of magnitude in summer and in winter and are generally larger in winter than in summer. This unexpected phenomenon is a result of chemistry. DMS is oxidized by $\mathrm{OH}$ and $\mathrm{NO}_{3}$ radicals only. Oxidation by $\mathrm{OH}$ largely dominates in summer $(\sim 99.5 \%$ of the total DMS oxidation in the Antarctic boundary layer) whereas oxidation by $\mathrm{NO}_{3}$ dominates in winter $(\sim 98.5 \%)$. This is due to the polar night that prevents $\mathrm{OH}$ radicals from forming and preserves $\mathrm{NO}_{3}$ radicals from photolysis. However, DMS loss due to oxidation by $\mathrm{NO}_{3}$ (in winter) is 100 times slower than DMS loss due to oxidation by $\mathrm{OH}$ (in summer), so that DMS lifetime is considerably increased in winter. A longer lifetime results in a more homogeneous spatial distribution. This is also reflected by the zonally averaged vertical distribution of DMS (Figure 17). Because of the rapid oxidation of DMS after its emission at the sea surface, the summer situation displays a strong vertical gradient (from $500 \mathrm{pptv}$ at the sea level to $1 \mathrm{pptv}$ at $8000 \mathrm{~m}$ at $60^{\circ} \mathrm{S}$ ) in comparison with winter situation (from $30 \mathrm{pptv}$ at the sea level to $6 \mathrm{pptv}$ at $8000 \mathrm{~m}$ at $60^{\circ} \mathrm{S}$ ). Relative to the quantity emitted, DMS is more abundantly transported upward in winter, and this strongly affects the atmospheric DMS load over the Antarctic continent. These results show that DMS surface measurements made at coastal sites may not reflect seasonality at higher elevations and inside the continent.

\subsection{Antarctic Sulfur Budget}

[44] Figure 18 presents the annual budget of sulfur species in the Antarctic region (defined as being south of $60^{\circ} \mathrm{S}$ ). The global budget is also reported between brackets. The global values are close to those of Boucher et al. [2002], who use the same model but with a regular grid and a different vertical resolution. Although its surface is $7 \%$ of the total surface of the globe, the Antarctic region only accounts for $1 \%$ of the total mass of $\mathrm{SO}_{2}$ and $2.6 \%$ of the sulfate, but $18 \%$ and $27 \%$ of the total mass of DMS and DMSO, respectively. Because of the high amount of DMS, oxidation of DMS by $\mathrm{OH}$ is a major component of the overall sulfur chemistry. The very high burden of DMSO in the Antarctic region is partly due to enhancement of the $\mathrm{DMS}+\mathrm{OH}$ addition channel (due to low temperature), and to the low level of $\mathrm{NO}_{3}$ in this region: DMSO production by the DMS + OH addition channel represents $25 \%$ of the DMS sink in Antarctica whereas it is only $15 \%$ at the global scale. The Antarctic burden of DMSO may be overestimated due to a missing heterogeneous sink of DMSO in the model, but on the other hand, DMS oxidation by $\mathrm{BrO}$ is not considered either (section 3.2). Thus, large uncertainties remain in the Antarctic DMSO burden. As a consequence of possible overestimation of the DMSO burden, the $7.8 \%$ of global MSA located in the modeled Antarctic region should be an underestimation. The main chemical sink of $\mathrm{SO}_{2}$ in the Antarctic region is oxidation by $\mathrm{O}_{3}$ in the aqueous phase, whereas it is oxidation by $\mathrm{H}_{2} \mathrm{O}_{2}$ at the global scale. Oxidation by $\mathrm{O}_{3}$ occurs all year-round, while in austral winter oxidation by $\mathrm{H}_{2} \mathrm{O}_{2}$ is reduced or stopped for several months. In one year, $0.98 \mathrm{TgS}(1 \%$ of the global sulfur emissions) is released within the Antarctic region whereas $1.33 \mathrm{TgS}(1.5 \%)$ are lost by wet and dry deposition. Therefore, local emissions and convergence from the lower latitudes both contribute to the Antarctic sulfur budget.

\section{Conclusions}

[45] The recent publication of annual timescale records of DMS and DMSO in Antarctica [Jourdain and Legrand, 2001; Jourdain, 2001], which complete longer time series of sulfate and MSA, motivated this study of the sulfur cycle at high-southern latitudes. An AGCM already including sulfur chemistry was optimized for polar regions using specific physical parameterizations [Krinner et al., 1997], a zoomed grid reaching $\sim 100 \mathrm{~km}$ resolution in Antarctica, and partial nudging to ECMWF data [Genthon et al., 2002]. This study of the atmospheric sulfur cycle in the Antarctic region leads to the following conclusions:

1. The model captures most of the seasonal signals observed at the Antarctic coast and, for DMS, at subantarctic stations. Many other 3D models underestimate 


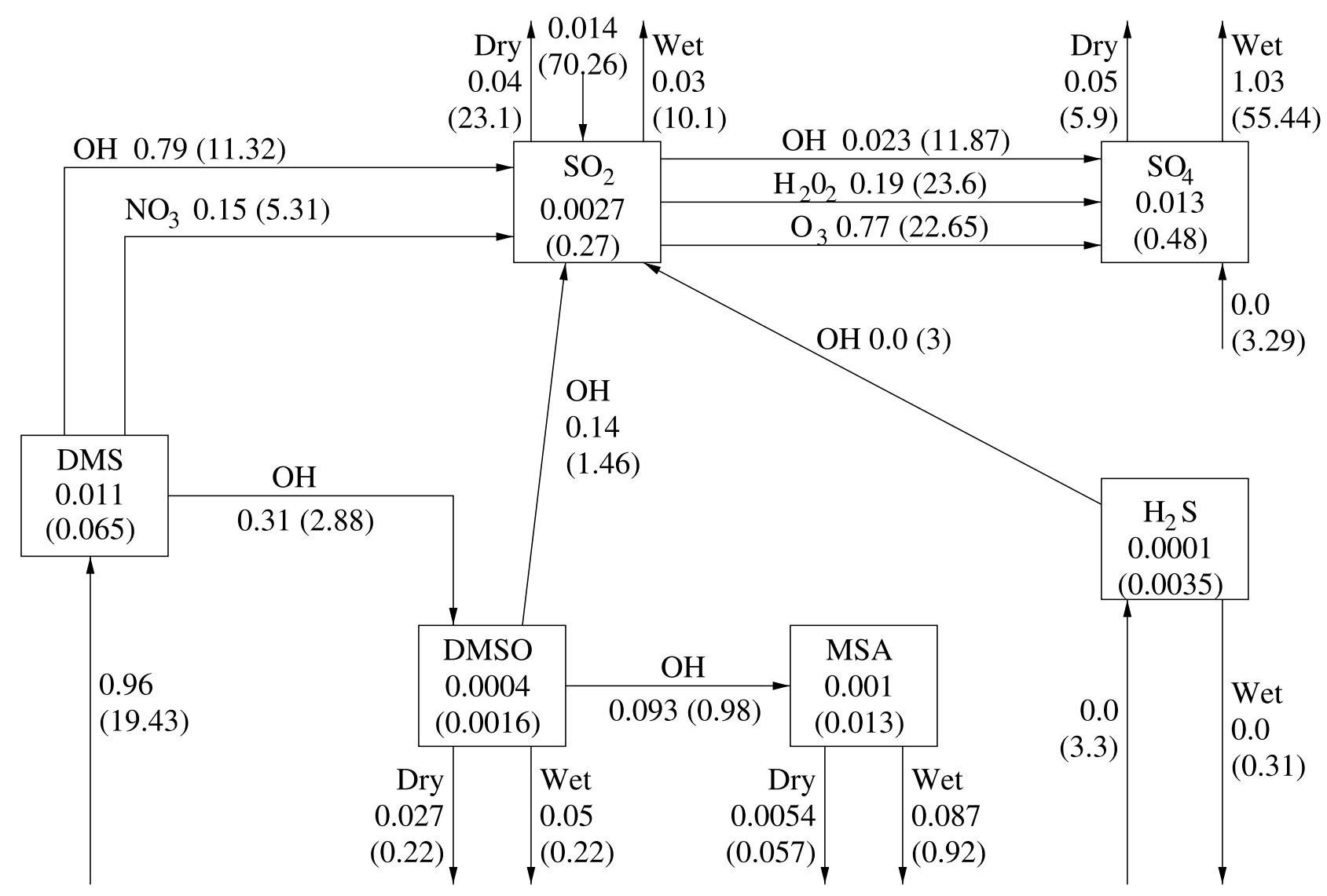

Figure 18. Annually averaged Antarctic $\left(>60^{\circ} \mathrm{S}\right)$ sulfur budget. Burdens are in TgS, and fluxes, deposition, and reaction rates in $\mathrm{TgS}_{\mathrm{yr}}{ }^{-1}$. "Dry" and "Wet" refer to dry and wet deposition. Numbers in parentheses refer to globally averaged values.

these seasonal cycles. Our results are partly due to a better quality of prescribed sources of oceanic DMS.

2. Seasonal variations of DMS appear to be strongly linked to the local emission fluxes of DMS.

3. DMSO is overestimated at Dumont d'Urville in summer, whereas an underestimation of MSA is obtained. This is consistent with the existence of an heterogeneous sink of DMSO leading to MSA, as suggested by Legrand et al. [2001], and ignored in the model. However, in spite of this missing sink, DMSO is well simulated at Amsterdam Island. At present time, understanding and quantification of heterogeneous DMSO oxidation is still insufficient to be routinely accounted for in global 3D models.

4. DMSO is underestimated at Dumont d'Urville in winter, more than DMS is. A missing reaction of DMS oxidation by $\mathrm{BrO}$ is suggested. The atmospheric levels of $\mathrm{BrO}$ are too poorly known presently and, although the kinetics are known, the reaction cannot yet be considered routinely in models.

5. The model underestimates atmospheric concentrations of nss sulfate and MSA at the South Pole. This might be in part due to a lack of $\mathrm{OH}$ radicals near the ground. Vertical mixing and aerosol deposition processes might be involved as well. Observations of the vertical distribution of concentrations of nss sulfate and MSA are needed to assess the role of each process.

6. Wet deposition of sulfate is exaggerated over the Antarctic continent. The deposition scheme used might not be adapted to the polar regions. The effects of ice precipitation should be distinguished from those of liquid precipitation in the in-cloud scavenging scheme.

7. The model cannot capture the interannual variability and the monthly relative anomalies of sulfur species, in spite of forcing with realistic changes in meteorology and sea ice cover. The variability of the oceanic concentrations of DMS has to be taken into account, for instance from long-term satellite measurements of the phytoplankton activity, in order to adequately model intraannual and interannual variations.

8. The model suggests very different behaviors for the seasonal cycle of DMS surface concentrations at the Antarctic coasts and inside the continent. Thus measurements performed at the coast are probably not representative of the overall sulfur cycle in Antarctica. Measurements of DMS inside the continent would be of great interest to confirm our model results.

9. The sulfur cycle at high-southern latitudes is characterized by high loads of DMS, DMSO and MSA, which reflect the importance of the DMS $+\mathrm{OH}$ addition channel at low temperatures. The main chemical sink of $\mathrm{SO}_{2}$ is aqueous oxidation by $\mathrm{O}_{3}$, whereas oxidation by $\mathrm{H}_{2} \mathrm{O}_{2}$ dominates at the global scale.

[46] Acknowledgments. We wish to thank M. Legrand, B. Jourdain, and J. Sciare for fruitful discussion, and we are grateful to M. Schulz for providing us output data from TM3 model. Computer time was provided by 
the Centre Grenoblois de Calcul Vectoriel (CGCV) of the Commissariat à l'Energie Atomique (CEA) and by the Institut du Developpement et des Resources en Informatique Scientifique (IDRIS). Sea surface temperature maps used as boundary conditions in the GCM come from the Met Office (GISST data). This work takes part in a research project supported by the Programme National de Chimie Atmospherique (PNCA) of the CNRS and by the Institut Polaire Français Paul-Emile Victor (IPEV).

\section{References}

Andreae, M. O., Ocean-atmosphere interactions in the global biogeochemical sulfur cycle, Mar. Chem., 30, 1-29, 1990.

Arimoto, R., A. S. Nottingham, J. Webb, C. A. Schloesslin, and D. D. Davis, Non-sea salt sulfate and other aerosol constituents at the South Pole during ISCAT, Geophys. Res. Lett., 28, 3645, 2001

Atkinson, R., D. L. Baulch, R. A. Cox, R. F. Hampson, J. A. Kerre Jr., and J. Troe, Evaluated kinetic and photochemical data for atmospheric chemistry: Supplement III, J. Phys. Chem. Ref. Data, 18, 881-1097, 1989.

Ayers, G. P., S. T. Bentley, J. P. Ivey, and B. W. Forgan, Dimethylsulfide in marine air at Cape Grim, $41^{\circ} \mathrm{S}, J$. Geophys. Res., 100, 21,013-21,021, 1995.

Barth, M. C., P. J. Rasch, J. T. Kiehl, C. M. Benkovitz, and S. E. Schwartz, Sulfur chemistry in the National Center for Atmospheric Research Community Climate Model: Description, evaluation, features, sensitivity to aqueous chemistry, J. Geophys. Res., 105, 1387-1415, 2000.

Bates, T. S., J. D. Cline, and R. H. Gammon, Regional and seasonal variations in the flux of oceanic dimethylsulphide to the atmosphere, J. Geophys. Res., 92, 2930-2938, 1987.

Bates, T. S., J. A. Calhoun, and P. K. Quinn, Variations in the methane sulphonate to sulphonate and molar ratio in submicrometer marine aerosol particles over the South Pacific Ocean, J. Geophys. Res., 97, 98599865, 1992a.

Bates, T. S., B. K. Lamb, A. Guenther, J. Dignon, and R. E. Stoiber, Sulfur emissions from natural sources, J. Atmos. Chem., 14, 315-337, 1992 b.

Bates, T. S., B. J. Huebert, J. L. Gras, F. B. Griffiths, and P. A. Durkee, International Global Atmospheric Chemistry (IGAC) Project's Firs Aerosol Characterization Experiment (ACE 1): Overview, J. Geophys. Res., 103, 16,297-16,318, 1998.

Benkovitz, C. M., C. M. Berkowitz, R. C. Easter, S. Nemesure, R. Wagener, and S. E. Schwartz, Sulfate over the North Atlantic and adjacent continental regions: Evaluation for October and November 1986 using three-dimensional model driven by observation-derived meteorology, J. Geophys. Res., 99, 20,725-20,756, 1994.

Berresheim, H., and F. L. Eisele, Sulfur Chemistry in the Antarctic Troposphere Experiment: An overview of project SCATE, J. Geophys. Res. 103, 1619-1627, 1998 .

Berresheim, H., J. W. Huey, R. P. Thorn, F. L. Eisele, D. J. Tanner, and A. Jefferson, Measurements of dimethyl sulfide, dimethyl sulfoxide, dimethyl sulfone, aerosol ions at Palmer Station, Antarctica, J. Geophys. Res., 103, 1629-1637, 1998 .

Blake, N. J., et al., Aircraft measurements of the latitudinal, vertical, seasonal variations of NMHCs, methyl nitrate, methyl halides, DMS during the First Aerosol Characterization Experiment (ACE 1), J. Geophys. Res. 104, 21,803-21,817, 1999

Boucher, O., M. Pham, and C. Venkataraman, Simulation of the atmo spheric sulfur cycle in the Laboratoire de Meteorologie Dynamique General Circulation Model: Model description, model evaluation, global and European budgets, Note Scientifique de l'IPSL, 2002. (Available as http:// www.ipsl.jussieu.fr/poles/Modelisation/NotesSciences.html).

Chapman, E. G., R. C. Easter, X. Bian, and S. J. Ghan, The influence of wind speed averaging an estimates of dimethylsulfide emission fluxes, J. Geophys. Res., 107, doi:10.1029/2001JD001564, in press, 2002.

Charlson, R. J., Gas-to-particle conversion and CCN production, in Dimethylsulfide: Oceans, Atmosphere and Climate, edited by G. Restelli and G. Angeletti, pp. 275-286, Kluwer Acad., Norwell, Mass., 1993.

Charlson, R. J., J. E. Lovelock, M. O. Andreae, and S. G. Warren, Oceanic phytoplankton, atmospheric sulphur, cloud albedo and climate, Nature, 326, 655-661, 1987.

Charlson, R. J., S. E. Schwartz, J. M. Hales, R. Cess, J. A. Coakley, J. E. Hansen, and D. J. Hoffman, Climate forcing by anthropogenic aerosols, Science, 255, 422-430, 1992.

Chatfield, R., and P. J. Crutzen, Are there interactions of iodine and sulfur species in marine air photochemistry?, J. Geophys. Res., 95, 22,31922,341, 1990

Chin, M., D. J. Jacob, G. M. Gardner, M. S. Foreman-Fowler, P. A. Spiro, and D. L. Savoie, A global three-dimensional model of tropospheric sulfate, J. Geophys. Res., 101, 18,667-18,690, 1996.

Chin, M., D. L. Savoie, B. J. Huebert, A. R. Bandy, D. C. Thornton, T. S Bates, P. K. Quinn, and E. S. Saltzman, Atmospheric sulfur cycle simu- lated in the global model GOCART: Comparison with field observations and regional budgets, J. Geophys. Res., 105, 24,689-24,712, 2000.

Cunningham, J., and E. D. Waddington, Air flow and dry deposition of non-sea salt sulfate in polar firn: Paleoclimatic implications, Atmos. Environ., 27A, 2943-2956, 1993.

Curran, M. A. J., The spatial and seasonal distribution of dimethylsulphide and dimethylsulfoniopropionate in the Great Barrier Reef, North Tasman Sea, Southern Ocean regions, Ph.D. thesis, James Cook Univ., Townsville, Queensland, Australia, 1996.

Curran, M. A. J., and G. B. Jones, Dimethyl sulfide in the Southern Ocean: Seasonality and flux, J. Geophys. Res., 105, 20,451-20,460, 2000

Curran, M. A. J., G. B. Jones, and H. Burton, Spatial distribution of dimethylsulfide and dimethylsulfoniopropionate in the Australian sector of the Southern Ocean, J. Geophys. Res., 103, 16,677-16,689, 1998.

Davis, D., G. Chen, P. Kasibhatla, A. Jefferson, D. Tanner, F. Eisele, D. Lenschow, W. Neff, and H. Berresheim, DMS oxidation in the Antarctic marine boundary layer: Comparison of model simulations and field observations of DMS, DMSO, DMSO ${ }_{2}, \mathrm{H}_{2} \mathrm{SO}_{4}(\mathrm{~g}), \mathrm{MSA}(\mathrm{g}), \mathrm{MSA}(\mathrm{p})$, J. Geophys. Res., 103, 1657-1678, 1998

Davis, D., et al., Unexpected high levels of NO observed at South Pole, Geophys. Res. Lett., 28, 3625-3628, 2001.

De Bruyn, W. J., T. S. Bates, J. M. Cainey, and E. S. Saltzman, Shipboard measurements of dimethyl sulfide and $\mathrm{SO}_{2}$ southwest of Tasmania during the First Aerosol Characterization Experiment (ACE 1), J. Geophys. Res., $103,16,703-16,711,1998$

DeMore, W. B., S. P. Sander, D. M. Golden, R. F. Hampson, M. J. Kurylo, C. J. Howard, A. R. Ravishankara, C. E. Kolb, and M. J. Molina, Chemical Kinetics and Photochemical Data for Use in Stratospheric Modeling, Evaluation Number 12, vol. 97-4, Jet Propul. Lab., Pasadena, Calif., 1997.

Erickson, D. J., A stability dependent theory for air-sea gas exchange, J. Geophys. Res., 98, 8471-8488, 1993.

Feichter, J., E. Kjellström, H. Rodhe, F. Dentener, J. Lelieveld, and G.-J. Roelofs, Simulation of the tropospheric sulfur cycle in a global circulation model, Atmos. Environ., 30, 1693-1707, 1996.

Genthon, C., and G. Krinner, The Antarctic surface mass balance and systematic biases in GCMs, J. Geophys. Res., 106, 20,653-20,664, 2001.

Genthon, C., G. Krinner, and E. Cosme, Free and laterally-nudged Antarctic climate of an Atmospheric General Circulation Model, Mon. Weather Rev., 130, 1601-1616, 2002

Guelle, W., M. Schulz, Y. Balkanski, and F. Dentener, Influence of the source formulation on modeling the atmospheric global distribution of sea salt aerosol, J. Geophys. Res., 106, 27,509-27,524, 2001.

Harder, S., S. G. Warren, and R. J. Charlson, Sulfate in air and snow at the South Pole: Implications for transport and deposition at sites with low snow accumulation, J. Geophys. Res., 105, 22,825-22,832, 2000.

Honrath, R. E., M. C. Peterson, M. P. Dziobak, J. E. Dibb, P. B. Shepson, and B. Campbell, Evidence of $\mathrm{NO}_{x}$ production within or upon ice particles in the Greenland snowpack, Geophys. Res. Lett., 26, 695-698, 1999.

Hoshiai, T., Autumnal proliferation of ice algae in Antarctic sea ice, in Antarctic Nutrient Cycles and Food Webs, edited by W. R. Siegfried et al., pp. 89-92, Springer-Verlag, New York, 1985.

Hourdin, F., and A. Armengaud, The use of finite-volume methods for atmospheric advection of trace species, part 1, Test of various formulations in a general circulation model, Mon. Weather Rev., 127, 822-837, 1999.

Hynes, A. J., P. H. Wine, and D. H. Semmes, Kinetics and mechanism of $\mathrm{OH}$ reactions with organic sulfides, J. Phys. Chem., 90, 4148-4156, 1986.

Inomata, Y., K. Matsunaga, M. Hayashi, K. Osada, and Y. Iwasaka, Volatile sulfur compounds in the atmosphere and seawater during Antarctic cruise of Shirase, paper presented at Symposium on Polar Meteorology and Glaciology, Natl. Inst. of Polar Res., Tokyo, 26-27 November 1997.

IPCC, Climate Change 2001, edited by J. T. Houghton et al., pp. 183-238, Cambridge Univ. Press, New York, 2001.

Jefferson, A., D. J. Tanner, F. L. Eisele, and H. Berresheim, Sources and sinks of $\mathrm{H}_{2} \mathrm{SO}_{4}$ in the remote Antarctic marine boundary layer, J. Geophys. Res., 103, 1639-1645, 1998a.

Jefferson, A., D. J. Tanner, F. L. Eisele, D. D. Davis, G. Chen, J. Crawford, J. W. Huey, A. L. Torres, and H. Berresheim, OH photochemistry and methane sulfonic acid formation in the coastal Antarctic boundary layer, J. Geophys. Res., 103, 1647-1656, 1998b.

Jourdain, B., Etude du maillon atmosphrique du cycle biogochimique du Soufre aux hautes latitudes Sud (station Dumont d'Urville), Ph.D. thesis, Univ. Joseph Fourier, Grenoble, France, 2001.

Jourdain, B., and M. Legrand, Seasonal variations of atmospheric dimethylsulfide, dimethylsulfoxide, sulfur dioxyde, methanesulfonate and non-sea-salt sulfate aerosols at Dumont d'Urville (coastal Antarctica) (December 1998-July 1999), J. Geophys. Res., 106, 14,391-14,407, 2001. 
Kasibhatla, P., W. L. Chameides, and J. S. John, A three-dimensional global model investigation of seasonal variations in the atmospheric burden of anthropogenic sulfate aerosols, J. Geophys. Res., 102, 3737-3760, 1997.

Kettle, A. J., et al., A global database of sea surface dimethylsulfide (DMS) measurements and a procedure to predict sea surface DMS as function of latitude, longitude and month, Glob. Biogeochem. Cycles, 13, 399-444, 1999

Kiehl, J. T., T. L. Schneider, P. J. Rasch, M. C. Barth, and J. Wong, Radiative forcing due to sulfate aerosols from simulations with the National Center for Atmospheric Research Community Climate Model, Version 3, J. Geophys. Res., 105, 1441-1458, 2000.

Kirst, G. O., C. Thiel, H. Wolff, J. Nothnagel, M. Wanzek, and R. Ulmke, Dimethylsulphoniopropionate (DMSP) in ice algae and its possible role, Mar. Chem., 35, 381-388, 1991.

Kleefeld, C., Investigations of the Seasonality of Atmospheric Dimethyl Sulfide in the Arctic and Antarctica, Alfred Wegener Inst. for Pol. and Mar. Res., Bremerhaven, Germany, 1998

Koch, D., D. Jacob, I. Tegen, D. Rind, and M. Chin, Tropospheric sulfur simulation and sulfate direct radiative forcing in the Goddard Institute for Space Studies general circulation model, J. Geophys. Res., 104, 23,79923,822, 1999.

Krinner, G., C. Genthon, Z. Li, and P. Le Van, Studies of the Antarctic climate with a stretched-grid general circulation model, J. Geophys. Res., 102, 13,731-13,745, 1997.

Langner, J., and H. Rodhe, A global three-dimensional model of the tropospheric sulfur cycle, J. Atmos. Chem., 13, 225-263, 1991

Legrand, M., Ice core records of atmospheric sulphur, Philos. Trans. R. Soc. London, 352, 241-250, 1997.

Legrand, M., C. Feniet-Saigne, E. S. Saltzman, and C. Germain, Spatial and temporal variations of methanesulfonic acid and non sea salt sulfate in Antarctic ice, J. Atmos. Chem., 14, 245-260, 1992.

Legrand, M., J. Sciare, B. Jourdain, and C. Genthon, Sub-daily variations of atmospheric dimethylsulfide, dimethylsulfoxide, methanesulfonate and non-sea-salt sulfate aerosols in the atmospheric boundary layer at Dumont d'Urville (coastal Antarctica) during Summer, J. Geophys. Res., $106,14,409-14,422,2001$

Levasseur, M., M. Gosselin, and S. Michaud, A new source of dimethylsulfide (DMS) for the Arctic atmosphere: Ice diatoms, Mar. Biol., 121, $381-387,1994$

Lide, D., , and H. P. R. Frederikse (Eds.), CRC Handbook of Chemistry and Physics, 76th Edition, CRC Press, Boca Raton, Fla., 1995

Liss, P. S., and L. Merlivat, Air-sea exchange rates: Introduction and synthesis, in The Role of Air-Sea Exchange in Geochemical Cycling, edited by P. Buat-Ménard, pp. 113-127, D. Reidel, Norwell, Mass. 1986.

Mauldin, R. L., F. L. Eisele, D. J. Tanner, and E. Kosciuch, Measurements of $\mathrm{OH}, \mathrm{H}_{2} \mathrm{SO}_{4}, \mathrm{MSA}$ at the South Pole during ISCAT, Geophys. Res. Lett., 28, 3629-3632, 2001.

Minikin, A., M. Legrand, J. Hall, D. Wagenbach, C. Kleefeld, E. Wolff, E. C. Pasteur, and F. Ducroz, Sulfur-containing species (sulfate and methanesulfonate) in coastal Antarctic aerosol and precipitation, J. Geophys. Res., 103, 10,975-10,990, 1998

Müller, J., and G. P. Brasseur, IMAGES: A three-dimensional chemica transport model of the global troposphere, J. Geophys. Res., 100, $16,455-16,490,1995$.

National Bureau of Standards, Selected Values of Chemical Thermodynamic Properties, 1, Tech. Notevol. 270-1, Gaithersburg, Md., 1965.

Nguyen, B. C., N. Mihalopoulos, and S. Belviso, Seasonal variation of atmospheric dimethylsulfide at Amsterdam Island in the Southern Indian Ocean, J. Atmos. Chem., 11, 123-143, 1990.

O'Sullivan, D., M. Lee, B. C. Noone, and B. G. Heikes, Henry's law constant determinations for hydrogen peroxide, methyl hydroperoxide, hydromethyl hydroperoxide, ethyl hydroperoxide, peroxyacetic acid, J. Phys. Chem., 100, 3241-3247, 1996.

Patroescu, I. V., I. Barnes, K. H. Becker, and N. Mihalopoulos, FT-IR product study of the $\mathrm{OH}$-initiated oxidation of dms in the presence of $\mathrm{NO}_{x}$, Atmos. Environ., 33, 25-35, 1996.
Pham, M., J. Müller, G. P. Brasseur, C. Granier, and G. Mégie, A 3D model of the global sulfur cycle, J. Geophys. Res., 100, 26,061-26,092, 1995.

Ravishankara, A. R., Y. Rudich, R. Talukdar, and S. B. Barone, Oxidation of atmospheric reduced sulphur compounds: Perspective from laboratory studies, Philos. Trans. R. Soc. London, 352, 171-182, 1997.

Roelofs, G.-J., J. Lelieveld, and L. Ganzeveld, Simulation of global sulfate distribution and the influence on effective cloud drop radii with a coupled photochemistry-sulfur cycle model, Tellus, 50B, 224-242, 1998.

Sander, R., Compilation of Henry's law constants for inorganic and organic species of potential importance in environmental chemistry (version 3 ), 1999. (Available as http://www.mpch-mainz.mpg.de/ sander/res/henry. html).

Savoie, D. L., J. M. Prospero, R. J. Larsen, F. Huang, M. A. Izaguirre, T. Huang, T. H. Snowdon, L. Custals, and C. G. Sanderson, Nitrogen and sulfur species in Antarctic aerosols at Mawson, Palmer station, and Marsh (King George Island), J. Atmos. Chem., 17, 95-122, 1993.

Sciare, J., M. Kanakidou, and N. Mihalopoulos, Diurnal and seasonal variation of atmospheric dimethylsulfoxide (DMSO) at Amsterdam Island in the Southern Indian Ocean, J. Geophys. Res., 105, 17,257-17,265, $2000 \mathrm{a}$

Sciare, J., N. Mihalopoulos, and F. J. Dentener, Interannual variability of atmospheric dimethylsulfide in the Southern Indian Ocean, J. Geophys. Res., 105, 26,369-26,377, 2000b.

Seinfeld, J. H., and S. Pandis, Atmospheric Chemistry and Physics: Air Pollution to Climate, 1326 pp., Wiley-Interscience, New York, 1998

Shaw, G. E., Bio-controlled thermostasis involving the sulfur cycle, Clim. Change, 5, 297-303, 1983.

Tans, P. P., I. Y. Fung, and T. Takahashi, Observational constraints on the global atmospheric $\mathrm{CO}_{2}$ budget, Science, 247, 1431-1438, 1990

Taylor, K. E., and J. E. Penner, Response of the climate system to atmospheric aerosols and greenhouse gases, Nature, 369, 734-737, 1994.

Tiedtke, M., A comprehensive mass flux scheme for cumulus parameterization in large-scale models, Q. J. R. Meteorol. Soc., 117, 1779-1800, 1989

Toumi, R., BrO as a sink for dimethylsulfide in the marine atmosphere, Geophys. Res. Lett., 21, 117-120, 1994.

Tuncel, G., N. K. Aras, and W. H. Zoller, Temporal variations and sources of elements in the South Pole atmosphere, 1, Nonenriched and moderately enriched elements, J. Geophys. Res., 94, 13,025-13,038, 1989.

Turner, S. M., P. D. Nightingale, W. Broadgate, and P. S. Liss, The distribution of dimethylsulfide and dimethylsulphoniopropionate in Antarctic waters and ice, Deep Sea Res., Part II, 42, 1059-1080, 1995.

Van Leer, B., Towards the ultimate conservative difference scheme, IV, A new approach to numerical convection, J. Comput. Phys., 23, 276-299, 1977.

von Glasow, R., R. Sander, A. Bott, and P. J. Crutzen, Modeling halogen chemistry in the marine boundary layer, 2, Interactions with sulfur and the cloud-covered MBL, J. Geophys. Res., 107(D17), 4323, doi:10.1029/ 2001JD000943, 2002.

Wolff, E. W., J. S. Hall, R. Mulvaney, E. C. Pasteur, D. Wagenbach, and M. Legrand, Relationship between chemistry of air, fresh snow and firn cores for aerosol species in coastal Antarctica, J. Geophys. Res., 103, 11,057$11,070,1998 \mathrm{a}$.

Wolff, E. W., M. R. Legrand, and D. Wagenbach, Coastal Antarctic aerosol and snowfall chemistry, J. Geophys. Res., 103, 10,927-10,934, 1998 b.

O. Boucher, Laboratoire d'Optique Atmosphérique, Université des Sciences et Technologies de Lille, CNRS, Bâtiment P5, F-59655, Villeneuve d'Ascq, France.

E. Cosme, C. Genthon, and P. Martinerie, Laboratoire de Glaciologie et Géophysique de l'Environnement, CNRS/OSUG, 54, rue Molière, B.P. 96, F-38402, Saint-Martin-d'Hères Cedex, France. (cosme@glaciog.ujfgrenoble.fr)

M. Pham, Service d'Aronomie, Université Pierre et Marie Curie, 4 Place Jussieu, Boîte 102, F-75252, Paris, France. 